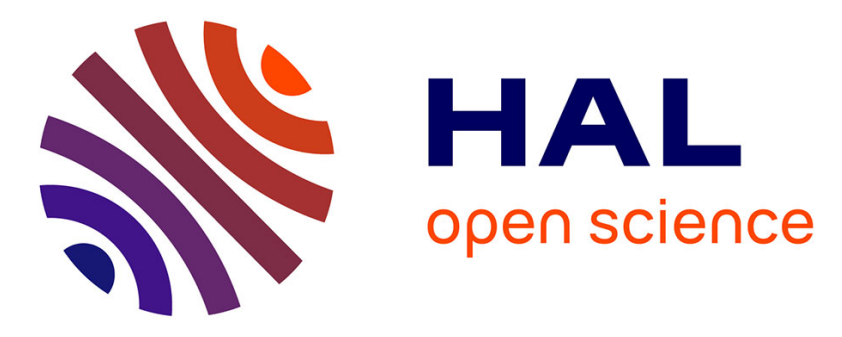

\title{
What's behind the tell phenomenon? An archaeozoological approach of Eneolithic sites in Romania
}

Stéphanie Bréhard, Adrian Bălăşescu

\section{- To cite this version:}

Stéphanie Bréhard, Adrian Bălăşescu. What's behind the tell phenomenon? An archaeozoological approach of Eneolithic sites in Romania. Journal of Archaeological Science, 2012, 39 (10), pp.31673183. 10.1016/j.jas.2012.04.054 . hal-02361401

\section{HAL Id: hal-02361401 \\ https://hal.science/hal-02361401}

Submitted on 13 Nov 2019

HAL is a multi-disciplinary open access archive for the deposit and dissemination of scientific research documents, whether they are published or not. The documents may come from teaching and research institutions in France or abroad, or from public or private research centers.
L'archive ouverte pluridisciplinaire HAL, est destinée au dépôt et à la diffusion de documents scientifiques de niveau recherche, publiés ou non, émanant des établissements d'enseignement et de recherche français ou étrangers, des laboratoires publics ou privés. 
What's behind the tell phenomenon? An archaeozoological approach of eneolithic sites in Romania

Stéphanie Bréhard, Adrian Bălăşescu

NOTICE: this is the post-print version of a work that was accepted for publication in Journal of Archaeological Science. Changes resulting from the publishing process, such as editing, corrections, structural formatting, and other quality control mechanisms may not be reflected in this document. Changes may have been made to this work since it was submitted for publication. A definitive version was subsequently published in Journal of Archaeological Science 39 (2012): 3167-3183.

Journal of Archaeological Science is available online at:

https://doi.org/10.1016/j.jas.2012.04.054 
What's behind the tell phenomenon? An archaeozoological approach of Eneolithic sites in Romania

Stéphanie Bréhard ${ }^{\text {a, b, * }}$

Adrian Bălăşescu ${ }^{\text {a }}$

${ }^{a}$ National History Museum of Romania, CNCP, Calea Victoriei nr. 12, 030026, sector 3, Bucharest, Romania

${ }^{\mathrm{b}}$ CNRS - Muséum national d'Histoire naturelle, UMR 7209, CP 56, 55 rue Buffon, F-75005 Paris, France

* Corresponding author. CNRS - Muséum national d'Histoire naturelle, UMR 7209, CP 56, 55 rue Buffon, F-75005 Paris, France.

E-mail address: brehard@mnhn.fr (S. Bréhard).

Fax number: +33140793314 . 


\section{Key-words}

Eneolithic; Hunting; Diversity; Pastoral practices; Sheep/goats; Specialization. functions existed. 


\section{Introduction}

The fifth and fourth millennia BC are fundamental for European societies because they correspond, depending on location, to the end of the Neolithization process (northern Europe) and to a new stage of development, described as a phase of increasing social complexity. In southeastern Europe, the fifth millennium BC is characterized by the development of copper metallurgy and it is during these two millennia that an accentuation of social differentiation occurred (Chapman et al., 2006; Guilaine, 2007; Marinescu-Bîlcu, 2001; Renfrew, 1978; Slavchev, 2008; Todorova, 1978). Some authors advance the hypothesis that it was specialization in Neolithic society that led to the development of social organization (Guilaine, 1998, 2007; Lichardus et al., 1985). In southeastern Romania, the fifth millennium $\mathrm{BC}$ is also characterized by the appearance of tell sites.

In southeastern Europe, specialized workshops have indeed been identified for these two millennia (Chapman, 2010; Ellis, 1984; Manolakakis, 2007), roughly corresponding to the Late Neolithic and Eneolithic period. In Romania, ceramic- and flint-processing areas are the most common (Marinescu-Bîlcu, 2002; Popovici, 2010). At Draguşeni (Cucuteni culture), it has even been demonstrated that a family specialized in an activity over many generations (Marinescu-Bîlcu and Bolomey, 2000). The hypothesis that some populations used communal granaries has also been advanced (Cârciumaru, 1996; Monah et al., 2003). Although the number of archaeozoological studies published for this period in Romania is high (Bălăşescu et al., 2003a, 2005a, 2005b; Bălăşescu and Radu, 2002, 2004; Cavaleriu and Bejenaru, 2009; El Susi, 1996), research dealing with the identification of specialization (of activities or places) is rare. The archaeozoological approach can be an effective tool for dealing with these questions. Much work has shown that the analysis of pastoral practices, for example, is an excellent way to reveal possible cases of specialization and thus to reveal the existence of exchanges between the sites of a given geographical zone (Arnold and Greenfield, 2006; Bréhard et al., 2010; Halstead, 1996; Helmer et al., 2005; Rowley-Conwy, 1991; Stein, 1987).

Our objective is to characterize the pastoral practices of some Eneolithic tell sites in Romania in order to identify possible cases of specialization and to define the relations that may have existed between the sites on a local or regional scale. To investigate the pastoral practices, reliable kill-off patterns were established for domestic ruminants. The intention of this paper is also to examine whether the appearance of a new type of settlement led to changes in overall animal exploitation systems. The tell sites, whose proper development begins in the middle of the fifth millennium BC in southeastern Romania, were both long-term occupations 
and organized settlements. Should the communities inhabiting this kind of settlement be

\section{Archaeological contexts}

The Hamangia culture covered a small geographical area on the western coast of the Black Sea, both in Romania and Bulgaria (Fig. 1). During the Early Hamangia, the settlements were generally short-term occupations, mostly small in size (Haşotti, 1997). These features partly changed during the Late Hamangia (phase III), which corresponds to the beginning of the fifth millennium BC (Voinea and Neagu, 2008).

The Boian culture is divided into three phases (Giuleşti, Vidra and Spanţov) that roughly cover the first half of the fifth millennium BC (Neagu, 2003; Pandrea, 2000; Table 1). The first occupations are located in the Muntenia region. Then the geographical area covered by the Boian culture changed over time. The late phase has been identified in the Muntenia and Dobrogea regions, also in the Marița culture in Bulgaria (Pandrea, 2000; Fig. 1). The Boian culture is characterized by more organized settlements. And the Vidra phase is marked by the appearance of successive occupations at the same place that resulted in tell sites in the Gumelniţa period. According to the chronology proposed by Petrescu-Dâmboviţa (2001), the Late Hamangia and the Boian culture belong to the Early Eneolithic.

The Gumelniţa culture spread across southern and southeastern Romania, the neighboring regions of the Republic of Moldova and Ukraine and the eastern part of Bulgaria (as Kodjadermen and Karanovo VI cultures; Fig. 1). Within this area, regional variants can be found (Marinescu-Bîlcu, 2001; Voinea, 2005). In Romania, the Gumelniţa culture dates from $4600 / 4500$ to 3500 cal BC according to the chronology proposed by several authors (Bem 
2001; Carozza et al., in press; Dumitrescu et al., 1983) and to recent radiocarbon dates (Cucchi et al., 2011; Ludwig et al., 2009; Tresset, personal communication 2011; Table 1). Two main phases can be distinguished in the evolution of the Gumelnița culture: phase A and phase B, each with two stages. The second phase (Gumelnița B) does not exist in the Dobrogea region (and its second stage, B2, is attested only in the hills of Muntenia and is known as the Brăteşti phase). About ten radiocarbon dates assigned to phase A are regarded as reliable (Table 1). They indicate occupations between 4600/4500 and 4000 cal BC. Three radiocarbon dates with very similar intervals are available for Gumelnița B1 (at Căscioarele, Bucşani and Vităneşti): from 3670 to 3500 cal BC and probably describe the end of the stage B1. The radiocarbon dates used in this paper have been calibrated $(2 \sigma)$ using Calib Rev 6.0.1 (Stuiver and Reimer, 1993). The Gumelniţa culture belongs to the Late Eneolithic (Dumitrescu and Vulpe, 1988; Petrescu-Dâmbovița, 2001).

\section{[Figure 1]}

\section{[Table 1]}

In southeastern Romania, the period of full development of the tell sites corresponds to the Gumelniţa culture. In southeastern Europe, the appearance and abandonment of the tell sites varies by areas. The fifth millennium BC is characterized by the appearance of the tell sites in southeastern Romania (and in northeastern Bulgaria; Todorova, 1978), while in the Carpathian Basin, there is the abandonment of this type of settlement. In the Great Hungarian Plain, the Tiszapolgár culture (Early Copper Age; 4600-4000 cal BC), which is contemporary with the Gumelnița A, is marked by the appearance of smaller settlements, dispersed in larger, regional settlement clusters (Parkinson et al., 2010).

Table 2 shows data about the Eneolithic sites included in the study (Andreescu and Lazăr, 2008; Andreescu et al., 2003; references in Bălăşescu et al., 2005a, 2005b; Bem, 2001; Boroneanț, 2000a; Comşa, 1990 ; Haită, 2002, 2005; Micu, 2005; Nica et al., 1995; Pandrea et al., 2009; Parnic et al., 2002; Popovici et al. 2000, 2001 and 2003; Şerbănescu and Trohani, 1978; Voinea, 2004-2005) while Figure 1 indicates the location of the sites. The Gumelnița tell sites present distinct features. The geological surroundings vary (islet, floodplain, hill in the floodplain, erosion remnant, river terrace), as do the shape and size of the tell sites. There are very large tells (at Hârşova tell, the base measures 200 x $150 \mathrm{~m}$ ) as well as small tell sites (at Vităneşti, the diameter at the base is $45 \mathrm{~m}$ ) and the preserved Gumelnița levels vary from 0.6 -7 $\mathrm{m}$ in height (Table 2). But in most cases, the height of the preserved Gumelnița levels 
varies from 1-3 m. Besides the main occupation of these tell sites dated to the Gumelniţa (Table 2).

All the Gumelniţa tell sites included in the study provided dwellings (often gutted by fire), which are characterized by floors made of silts or sandy silts. At the oldest excavations, these structures, if not gutted by fire, were sometimes not recognized as dwellings; these silty levels were interpreted as natural deposits. Pedologic, sedimentological and micromorphological analyses conducted during the last ten years threw new light on both the interpretation of the archaeological structures and the tell formation (Haită, 2000, 2001, 2002, 2003, 2005). Areas of household refuse have also been identified on the tell sites. These are the result, among other things, of mammals, fishes, mollusks and cereals processing (e.g., Haită and Radu, 2003; Moise, 2000; Monah, 2000). Burials have also been excavated at several tell sites (Hârşova tell, Căscioarele, Borduşani-Popină, Năvodari, Chitila; Bucşani); the skeletons are often under the floor of a dwelling (Boroneanț, 2000a; Dumitrescu et al., 1983; MarinescuBîlcu, 2001; Popovici et al., 2001, 2003).

The fact that dwellings were often rebuilt at the same place, according to the same plan, suggests that the Gumelnița tell sites were organized settlements (Marinescu-Bîlcu, 2001; Popovici et al., 2001); for most of the tell sites included in the study, the function of permanent settlement is proposed (Haită and Radu, 2003; Marinescu-Bîlcu, 2001; Popovici et al., 2000, 2001). At Căscioarele, the existence, in the Gumelnița B1 levels, of an annex where statuettes, bone figurines, anthropomorphic and zoomorphic pottery vessels and miniature chairs have been excavated (Marinescu-Bîlcu, 2001) suggests that unusual practices (independent of the everyday activities) also took place at some of these settlements (painted pillars have also been excavated in the Boian levels, and were interpreted as a sanctuary). On the basis of published information, no other Gumelniţa site included in the study provided such finds (but isolated statuette or portable altar, for example, has been identified in some dwellings). The function of the Gumelniţa tell sites is still unclear, as no overall study has been published yet; only preliminary results or studies regarding a small part of the excavated structures exist.

The duration of the Gumelniţa occupations is difficult to estimate. First, there are not enough radiocarbon dates per tell site and per stage (see Table 1) to propose even rough estimations. Moreover, very few Gumelnița A, or Gumelnița B, occupations have been entirely excavated in height (it has been done for the stage B1 at Căscioarele and Bucşani). For the moment, only small scale studies exist. At Hârşova tell, the micromorphological and ichthyological analyses 
carried out on an area of household refuse showed that the $50 \mathrm{~cm}$ accumulation corresponds to

\subsection{Material \\ 3.1.1. Faunal assemblages}

Faunal assemblages from funerary contexts are not included. We exclude very small samples (NISP $<67$; and only two assemblages out of 39 have less than 100 NISP). Almost half the assemblages selected are characterized by large samples (NISP $>1000,18$ cases out of 39; Table 3). Eleven sites out of the 29 selected in the study are still excavated (Table 2). As excavations began at least ten years ago, the available faunal assemblages are large enough to provide reliable information (the sample exceeds 1000 NISP in 10 cases out of 13). We exclude antler remains from the analyses except when studies do not go into any detail on this point (only six cases out of 39; Table 3).

It is not always specified in the archaeozoological studies from which archaeological structures the faunal remains come from ("cultural level"; 10 sites out of 29; Table 2). In the Gumelnița culture (and, to a lesser extent, some Boian occupations), the animal remains are mostly well preserved (Bălăşescu, 2003; Bălăşescu and Radu, 2004) thanks to the type of site: the tell sites are stratified settlements whose survival results from very specific 
conditions (in particular a dry climate) that reduce the process of erosion and preserve evidence of human activities. Hârşova tell and Borduşani-Popină have produced several wooden platforms (Popovici et al., 2000, 2003), which are evidence of low level degradation that characterizes most of the tell sites.

Sieving is carried out at some Eneolithic sites since the nineties only; therefore it concerns 10 sites out of the 29 included in the study (Table 2). At the others, the bone remains were collected by hand, so differential collection must be taken into consideration. For some of the oldest excavations (at Căscioarele, Vlădiceasca and Tangâru), this recovery bias is likely to be more obvious, due to the excavating methods. The identification of the assemblages highly biased by excavating and recovery methods is based on the presence of small taxa, such as Mustelidae, hare, birds, tortoise and fish. At Vărăşti, Vlădiceasca, Şeinoiu, Tangâru and Drăgăneşti-Olt (eight assemblages), no remains of birds, tortoise or fish and very few remains of hare and Mustelidae have been identified (Bălăşescu et al. 2005a; Bălăşescu and Radu, 2004). Therefore, the importance of small mammals in the economic systems is likely to be underestimated at these five sites. At Căscioarele, the same tendencies are observed for birds, tortoise, hare and Mustelidae; fish represent $10 \%$ of the faunal remains that have been collected (Dumitrescu, 1965). These two assemblages are biased by excavating and recovery methods but probably less than the others.

The 39 Eneolithic assemblages are different, both from the qualitative and quantitative point of view. This will be taken into consideration to interpret the results. To facilitate this, the names of the ten most reliable assemblages are in bold type in Table 3 and in the plots shown in Figs. 3, 4 and 5. This selection is based on several criteria (Tables 2 and 3): sample size (NISP > 800), excavating methods and recovery techniques (sieving).

Figure 1 indicates the locations of the 29 sites selected for the study. They provide 39 faunal assemblages belonging to the Hamangia, Boian and Gumelniţa cultures (Tables 2 and 3). Thirteen Boian assemblages characterizing the three phases of this culture are included in the study (Table 2). In three cases, Boian and Gumelnița archaeozoological studies are available for the same site. Six archaeozoological studies are published for the Hamangia culture in Romania but only three provide raw data (Bălăşescu and Radu, 2004). They are assigned to the late phase (phase III). Twenty-three faunal assemblages assigned to the Gumelnița culture are available (Table 2). In four cases, the same tell site provides archaeozoological studies illustrating two or three different stages of the culture (Table 2). Fifteen taxonomic spectra represent phase A (stage A2 is the best known: 14 assemblages out of 15) and seven phase B 
(stage B1 as there is no archaeozoological data published for stage B2). For one tell site, Tangâru, the phase is not known.

[Table 3]

For the Gumelnița tell sites, all the published archaeozoological studies characterize only a part of the occupation: either the Gumelniţa levels have not been entirely excavated or, for the two sites where the whole Gumelnița B occupation has been excavated, the study included only a part of the faunal remains (stage B1 at Bucşani and at Căscioarele). The faunal remains always come from several archaeological structures, often of different kinds (Table 2). The data used in this study are, for each cultural stage, global data. It is not possible to provide several faunal spectra per site, each of them characterizing a distinct archaeological structure. For the oldest archaeozoological studies, only the global faunal spectra are published. For the eight tell sites of which one of us (AB) is in charge of the study of the faunal remains (see Table 3), the stratigraphic profiles are not completed. It will be possible to work on a smaller scale and compare the different structures that have been excavated for one occupation, when the final stratigraphic data is available. A few studies regarding one archaeological structure are however available for five tell sites (Table 3): Hârşova tell (areas of household refuse C521 and C720, the outer level of a dwelling C1017), Borduşani-Popină (dwelling SL33, foundation trench C201), Luncavița (dwelling C4 and area of household refuse C2), Însurăței (dwellings L4, L7, L8) and Bucşani (dwelling L2). We will compare these 11 structures with the global data.

\subsubsection{Dental assemblages}

To discuss the pastoral practices, we selected five tell sites with distinct features. BorduşaniPopină, Hârşova tell and Măriuţa are characterized by an animal economy based mainly on husbandry while hunting played a major role at Luncaviţa and was predominant at Vităneşti. Cattle dominate the faunal spectrum at Măriuța, Vitănești (A2) and Luncavița, while sheep/goats are predominant at Hârşova tell. There is a more balanced representation of cattle and sheep/goats at Borduşani-Popină. These examples both date to Gumelnița A2 and B1. Large faunal assemblages are available; the size of the sample exceeds 100 teeth in five cases out of nine (see Tables 5 and 6). Sieving was carried out at four sites out of five (Table 2). At Borduşani-Popină, Hârşova tell and Luncaviţa, all the archaeological structures with a high archaeozoological potential have been sieved. For each site, the dental remains come from 
different archaeological structures. Only global kill-off patterns are given since stratigraphic

\subsection{Methods}

\subsubsection{Taxonomic identification}

In the archaeozoological studies included (see Table 3), identification to species level for Bovinae (cattle, Bos taurus, and aurochs, Bos primigenius) and Suinae (pig, Sus domesticus, and wild boar, Sus scrofa) is based on the osteometric and morphological criteria proposed by Bökönyi (1972), Bökönyi and Bartosiewicz (1997), Degerbøl and Fredskild (1970), El Susi (1996) and Manhart (1998). For sheep and goats, discrimination is based on the criteria proposed by Boessneck et al. (1964), Clutton-Brock et al. (1990) and Prummel and Frisch (1986). For the taxonomic determination that we conducted on teeth (see Table 3), we singled out the criteria developed for the premolars (Halstead et al., 2002; Helmer, 2000; Payne, 1985; Zeder and Pilaar, 2010). When isolated, the dP4 were not used to make taxonomic identifications.

\subsubsection{Analysis of the faunal spectra}

Our objective is to investigate whether the animal exploitation systems were homogeneous within each culture or whether diversity in the economic strategies occurred in the Gumelnița period (and if so, which species is related to which site(s)). Since we had to analyze together 39 assemblages and more than ten variables (taxa; Table 3), correspondence analysis (CA) was employed as the most suitable tool to achieve this purpose. The simultaneous consideration of multiple categorical variables can reveal relationships that would not be detected in a series of pair comparisons of variables (Bølviken et al., 1982; Clouse, 1999; Smith and Munro, 2009). CA allows the introduction of small assemblages, as the process characterizes each row (assemblages) and each column (taxa) by its profile (relative frequencies). This partly solves the problem of differences in sample size. The rules for interpreting the graphic display of row and column points in biplots are outlined by Bølviken et al. (1982; see also the summary in Smith and Munro, 2009). Data analyses were conducted with SPAD 4.

We selected 11 taxa as variables (Table 3). We exclude beaver, as it is present in only half the assemblages. As the frequencies for each of the ten species of wild carnivore (details are given in Table 3) are too low to justify their use independently, the species are treated as one 
large group. One purpose for hunting wild carnivores (and beaver) was for their pelts, but they were also eaten (identification of fragmented bones and of cutmarks from different kinds; Bălăşescu and Radu, 2002; Bălăşescu et al., 2003b, 2005a, 2005b). Dogs were also part of the diet (identification of dismembering and filleting marks; Bălăşescu et al., 2003b; Bălăşescu and Radu, 2003, 2004; Moise, 1997, 2001b). The fact that in most cases the (numerous) remains of Suinae could not be identified to species level led us to add the group "Sus sp." as a variable. However, since archaeozoological studies do not usually propose this taxonomic class, it is introduced as a supplementary variable (it does not contribute to the factor axes). Conversely, the taxonomic categories Bos sp. and Equus sp., are eliminated because they exist in only a few cases (less than ten assemblages out of 39).

\subsubsection{Kill-off patterns}

A way of examining the pastoral practices is the establishment of reliable kill-off patterns, constructed from the estimates of age at death of the animals (Arnold and Greenfield, 2006; Bréhard et al., 2010; Helmer et al., 2005; Rowley-Conwy, 1991; Stein, 1987). The kill-off patterns should be organized using relatively narrow age classes with a correspondence in absolute age to permit interpretations in terms of practices.

For cattle, we estimated the age at death from the stages of tooth eruption and replacement given by Higham (1967) and from the abrasion indexes proposed by Ducos (1968) for the molars. Precedence was always given to eruption development over wear. For sheep/goats, we used the method perfected by Helmer (1995; see Vigne and Helmer, 2007). When the molars were not measurable, Payne's wear stages were used.

The age classes retained for sheep/goats are those proposed by Helmer (1995; modified after Payne, 1973). For cattle, we adopted those advanced by Ducos (1968) for the adults, while the first three age classes are based on the stages given by Higham (1967).

The kill-off patterns were constructed based on the number of teeth (N; Vigne, 1988). We excluded the second premolars as we observed high variability in their wear stages, even at the very beginning of usage. When the estimate covered several age classes, the number of teeth was divided according to the size of the time bracket of each age class. We included only the lower teeth. Estimates based on upper teeth are less precise because upper jaws are more fragile, and teeth are often isolated.

We do not provide species-level kill-off patterns for sheep/goats, but do provide profiles including all the teeth whose age can be determined, as a precaution, following Helmer (2000) and Zeder and Pilaar (2010). The Ovis/Capra ratio is given (see Table 4). 
To investigate the pastoral practices of the tell sites selected, we first examined the possible biases, such as differential preservation or collection. The interpretations are based on works dealing with traditional farming, modern free-range management systems and feral populations.

\section{Animal exploitation systems}

4.1. The transition from Boian (and Hamangia III) to Gumelnița culture

Figure 2 clearly shows that changes in the meat component of the diet occurred between the Boian (and Hamangia III) and the Gumelnița cultures in southeastern Romania. Cattle obviously played a less important role during the Gumelniţa period, while hunting increased. A Chi-square test, carried out for the Boian and the Gumelnița cultures based on the remains (NISP) accumulated for each of the five taxa selected in Figure 2, confirms that the economic strategies varied according to the cultural group $\left(\chi^{2}=7134.4 ; \mathrm{df}=4 ; \mathrm{p}<0.0001\right)$. The Hamangia culture is also different because of the very low percentages of Suinae and dog (on average $2 \%$ and $1.8 \%$ of the faunal spectrum, respectively; Table 3 ). Suinae, for example, are not so rare on the Boian sites (from $0 \%$ to $24.8 \%$ of the faunal spectrum; average: $11.4 \%$ ); the difference is even statistically significant $(Z=23.48$; $p<0.001)$. However, only three reliable faunal assemblages are available for this culture.

\section{[Figure 2]}

The next step was to examine whether these main tendencies are true for all the Gumelnița sites or whether diversity in the economic strategies occurred in this period, and, if so, which species is related to which site(s). An initial correspondence analysis led to treating the dog as a supplementary variable: its contribution to the second factor axis was too high (32\%) in comparison to the low number of points that expressed this variable (2 out of 39: BorduşaniPopină and Hârşova tell).

Figure 3 is a plot of both assemblages and taxa for the first two factor axes. The contribution of these two factor axes to the total variance $(0.588)$ is $74.6 \%$. The first factor axis (horizontal; $56.1 \%$ of the total variance) contrasts red deer $(26.9 \%)$, aurochs (12\%), wild boar (11.9\%) and wild horse (10.2\%), on the left, with cattle (25.6\%) and sheep/goats (10.7\%), on the right. This is interpreted as an opposition between hunting and husbandry. The second axis (vertical; $18.6 \%$ of the total variance) contrasts in particular cattle $(27.8 \%)$, at the top of 
the plot with pig (23.5\%), and sheep/goats (19.3\%) at the bottom. We interpret this as the existence of different husbandry strategies.

Most objects (29 out of 39) are located on the right side of the plot, with cattle and sheep/goats. The domestic ruminants did play a major role in the economic systems of the Boian (and Late Hamangia) and Gumelnița cultures. All the sixteen objects representing the Hamangia and Boian cultures (in grey) are plotted on the right side, with cattle and sheep/goats, and twelve are located in the same quadrant (with cattle). This indicates that food supply strategies of the Hamangia (phase III) and Boian cultures were quite homogeneous and that they were based on domestic ruminant husbandry. It is likely that the importance of sheep/goats is underestimated for these cultures, as sieving was carried out at only four sites out of 14 . However, sheep/goats are predominant at two sites where remains were collected by hand (Siliştea-Conac and Lăceni-Măgura; Boian Giuleşti).

Conversely, the 23 Gumelnița assemblages (in black) are plotted in the four quadrants, which means that various taxa played a role in the economic systems. This scattering is accurate as the most reliable assemblages for the Gumelnița culture (7) are also plotted in the four quadrants (Fig. 3 and Table 3). This difference between the Boian (and Late Hamangia) culture and the Gumelnița also exists at a small scale level. At Căscioarele and Hârşova tell, where faunal assemblages are available for both the Boian Spanțov and the Gumelnița cultures (Table 3), changes in the meat component of the diet are obvious. At the former, red deer replaced cattle (Fig. 3). At Hârşova tell, pig and dog took the place of cattle.

[Figure 3]

\subsection{Hunting}

Ten Gumelniţa assemblages out of the 23 are located on the left side, with the wild mammals. Four of them belong to the category of the most reliable assemblages (Fig. 3; Table 3). At Căscioarele, Vităneşti (Gumelnița A2 and B1), Însurăței, Luncavița, Carcaliu, Drăgăneşti-Olt (Gumelniţa A2 and B1), Seciu and Bucşani, hunting occupied an essential place in the economy: from $29 \%$ to $84 \%$ of the faunal spectrum (average: $50 \%$; Table 3 ). The highest percentage, observed at Căscioarele, is probably wrong. Given the excavating and recovery methods used at this tell site (see 3.1.1. above), all the possible remains from small domestic mammals (e.g., sheep/goats and young pigs) have not been collected. Therefore, it is highly likely that the proportion of large mammals (of large game) is overestimated. However, the average hunting rate calculated for these ten assemblages (50\%) is correct as it is the same 
than the one based on the four most reliable assemblages (51\%; Table 3). For the 13

Gumelnița points located on the right side of the plot, with cattle and sheep/goats, wild mammals represent on average $16 \%$ of the faunal spectrum (the average for the three most reliable assemblages is $20 \%$; Table 3 ). If we exclude the remains of aurochs and wild boar, for which species-level identifications are debatable, wild mammals retain an essential place for the first group (from $23 \%$ to $78 \%$ of the faunal spectrum; average: $40 \%$ ) in comparison to the 13 others sites (average: 9\%). Moreover, this does not result from differences in sample size or from differential collection as the ten assemblages present various characteristics (half of them are quite small assemblages, from 309 NISP to 822, and sieving was conducted at some sites). The higher hunting rates observed are thus indisputable.

Some differences can be observed among these eight tell sites. To show this, the second factor axis is replaced by the third one ( $10.9 \%$ of the total variance) in the correspondence plot (Fig. 4). It contrasts red deer (28.4\%) and wild boar (4.3\%), at the top, with aurochs (21.6\%), wild horse $(3.8 \%)$ and wild carnivores $(3.7 \%)$, at the bottom. We interpret this as indicative of the existence of two distinct strategies: red deer (and wild boar) were mainly hunted at Căscioarele, Carcaliu, Luncaviţa and Drăgăneşti-Olt (in the upper half) while at Vităneşti and Însurăței (in the lower half) aurochs (and wild horse) are predominant. These differences are accurate as there are reliable assemblages in both groups (Fig. 4; Table 3). Red deer represent $50.2 \%$ to $73.4 \%$ of the wild taxa in the first group while the percentages are between $17.4 \%$ and $30.7 \%$ in the second group. The aurochs frequencies range from $23.2 \%$ to $31 \%$ at Vităneşti and Însurăței, and only $0.5 \%$ to $10.1 \%$ in the first group. This difference is shown in Figure 5. Bucşani presents a more balanced profile. At Seciu, the sample of wild species is too small to be reliable (NISP $<100$ ). These two strategies are neither a reflection of differential discrimination since the same archaeozoologist worked on half of the studies (Table 3), nor the difference is due to differential collection as only large mammals are concerned. It is possible that these distinct strategies are related to different landscapes, since red deer and wild boar are indicative of forested areas, while wild horses of grasslands. But the archaeobotanical data dealing with landscape reconstructions are too few to be applied.

\section{[Figure 4]}

[Figure 5]

\subsection{Husbandry}


For the domestic species, the first correspondence plot (Fig. 3) distinguishes the Gumelnița sites where cattle were predominant (14 faunal assemblages in the upper half) from those with sheep/goats and pigs ( 7 points in the lower half). The last two faunal assemblages (Luncavița and Mariuța; with coordinates very close to zero on the second factor axis) present a more balanced profile. Cattle thus appear to have been the most common domestic species, whatever the overall animal exploitation system. However, given the absence of sieving at 11 tell sites (out of 18; see Table 2), it is likely that the proportions of the smaller taxa, such as sheep/goats, are underestimated in some cases. It is noticeable that at the three sites where cattle provide at least $50 \%$ of the faunal spectra (six assemblages: Gumelnița A2 and B1, Vlădiceasca A1, A2 and B1 and Şeinoiu), remains have been collected by hand (Vlădiceasca and Şeinoiu have been characterized as assemblages highly biased by excavating and recovery methods; see 3.1. above). Conversely, sieving was carried out at the three tell sites where sheep/goats dominate (Hârşova, Năvodari and Sultana). Pigs are predominant only at Borduşani-Popină, but have the same importance as cattle at Seciu and Vităneşti (A2 and B1). Sheep/goats are more often in second place than pigs.

The ratio Ovis/Capra can be calculated reliably only for eight faunal spectra (Bălăşescu, 2003 and unpublished; Bălăşescu et al., 2005a; Moise, 1997, 2000, 2001a, 2001b). Sheep are clearly predominant (3 sheep for 1 goat) at Borduşani-Popină, Hârşova tell, Măriuța and Vitănești (A2 and B1). At Luncavița, Vlădiceasca (A2) and Năvodari, there is a more balanced representation of sheep and goats. For five sites, we can compare these results to those based exclusively on teeth (Table 4). They confirm the predominance of sheep at Borduşani-Popină, Hârşova tell and Măriuța. The percentages of sheep are even higher (four sheep for one goat). This could be the consequence of a more systematic and advanced taxonomic discrimination, as all the dental remains were displayed and analyzed at the same time. At Vităneşti and Luncavița, the number of mandibles identified to species level is too small $(\mathrm{N}=9)$ to be reliable. Variability likewise exists within the Caprinae, and there is no link between the predominance of sheep or goats and the overall animal exploitation systems (preponderance of husbandry or hunting).

[Table 4]

\subsection{Chronological variation}

The faunal assemblages dated to the Early (phase A) and to the Late (phase B) Gumelniţa appear both on the right side and on the left side of the first correspondence plot (Fig. 3; there 
are reliable assemblages in both groups). The cultural phase and the rate of hunting thus (phase B1) are located at the top of the plot. We interpret this as a decrease in the importance of sheep/goats during the second phase of the Gumelnița period (sieving was conducted at some sites). A Chi-square test, based on the remains (NISP) accumulated for each of the nine taxa selected as variables, confirms that the economic strategies varied according to the time period $\left(\chi^{2}=1563.1 ; \mathrm{df}=8 ; \mathrm{p}<0.0001\right)$. However, the number of available faunal spectra for Late Gumelnița is low and this hypothesis needs to be confirmed.

This study leads to the conclusion that the homogeneity of the animal exploitation systems during the Hamangia (phase III) and Boian period was followed by a greater diversity in the economic strategies. The main change is obviously the important role that hunting played for some Gumelnița communities (the favored species varied). Variability existed however within the domestic species as well.

\subsection{Intra-site comparisons}

To get an estimate of the variability in economic strategies on the settlement scale, we compared, at five tell sites, the global data with data coming from distinct archaeological structures (Table 3). We added the 11 faunal spectra as supplementary objects in the first correspondence plot. Figure 6 shows that, except in one case (Însurăței L4), the global faunal spectrum and the archaeological structures are in the same quadrant. Intra-site variability existed, but, according to the available data, it seems to have been limited. The three tell sites with high hunting rates (Însurăţei, Luncavița, Bucşani) did not provide archaeological structures characterized by a predominance of domestic mammals. The reverse is true as well (Borduşani-Popină and Hârşova tell). At Însurăței, the variability is due to differences in wild horse proportion. At Hârşova tell, it is caused by differences in sheep/goats (and cattle) percentage.

[Figure 6]

\subsection{Greater diversity in the animal exploitation systems during the Gumelnița period: possible explanations}

For Bovinae and Suinae, the taxonomic identifications distinguishing domestic and wild animals are debatable. Recent research based on DNA analysis has shown that some large 
Bovinae from Romania, probably aurochs according to osteometric criteria, have domesticlike haplotypes (haplotype T; Tresset, personal communication 2011). Hunting rates may be less for the Gumelniţa culture. On the other hand, it is an undeniable fact that very few bone remains are assigned to large Bovinae (categories Bos sp. and Bos primigenius) and to large Suinae (categories Sus sp. and Sus scrofa) in the Boian and Hamangia cultures, whereas these taxonomic categories present high frequencies for Gumelnița. Species-level identifications were in both cases based on the same criteria (see 3.2.1. above) and were conducted in some cases by the same archaeozoologist. Large animals did appear with the Gumelnița culture. Besides the aurochs hypothesis, the appearance of large oxen must be considered. However, evidence of osteological trauma related to work is rare on cattle remains for this period (Bălăşescu et al., 2006). Only occasional use appears possible (Bartosiewicz et al., 1997; Johannsen, 2006). Castration, reflecting a desire to increase meat yield, is perhaps more likely. For Suinae, post-domestication introgression between wild and domestic populations is possible, as well as the introduction of pigs from other geographical areas.

Hunting rates may be less for the Gumelniţa culture; nevertheless we demonstrated that wild mammals (especially red deer and wild horse; see 4.2. above) did play an important role for some Gumelniţa communities. The eight Gumelnița tell sites with high hunting rates have no obvious common characteristic, in terms of the type of tell (hill in the floodplain, islet and river terrace), cultural phase (they are assigned to phases A2 and B1) or geographical area (they are located in Dobrogea and Muntenia). Hunting rates are not linked to the duration of the Gumelnița occupation. Însurăței Popină I, Hârşova tell and Borduşani-Popină, which are the largest tell sites included in the study and where the preserved Gumelnița levels reach about $7 \mathrm{~m}$ in height (Table 2), are characterized both by high (Însurăței) and low proportions of wild mammals. Both cases also exist at the tell sites where the preserved Gumelnița levels are less than $1.5 \mathrm{~m}$ in height (Carcaliu and Bucşani-B1, on the one hand, and Măriuța and Năvodari on the other; Table 2). Therefore, it is likely that this phenomenon resulted from distinct factors.

The high hunting rates that appeared with the Gumelniţa culture could have been a reaction to unstable periods related to environmental changes. This mechanism is well known, based on Neolithic lake shore settlements in Central Europe, where high levels of hunting occurred during short periods of climatic deterioration (Arbogast et al., 2006; Schibler and Jacomet, 2010). For Gumelnița, this would imply that several unstable periods occurred, as the settlements with high hunting rates were occupied during different periods of time. Indeed, phase A2 at Vităneşti and Luncavița is roughly dated to between 4350 and 4200 cal BC while 
phase B1 at Vităneşti and Căscioarele is roughly dated to between 3670 and 3500 cal BC (Table 1). A period of climatic deterioration, which resulted in more humid climatic conditions according to Tomescu (2000), has indeed been identified for the second half of the fifth millennium BC. In the examples discussed by Schibler and Jacomet (2010), hunting focused on large mammals that provided high meat yield, for example red deer, and species diversity among prey animals is much reduced during periods of climatic deterioration. For the Gumelniţa settlements, no such decrease in species diversity is observed among sites with high numbers of wild mammal remains (Fig. 7). According to these criteria, the hypothesis of a response to occasional instability seems unlikely. However, the available Gumelnița faunal assemblages do not reflect short-term occupation, unlike those published for the lake shore settlements. Current archaeological research, with the objective of distinguishing occupation phases of the tell sites, will provide more precise information on economic changes through time on the settlement scale.

\section{[Figure 7]}

An increase in the exploitation of large game (aurochs, wild boar and red deer) also occurred in the Late Neolithic of the Carpathian Basin (Bartosiewicz, 2005). And, like the sites of the Gumelniţa period, these sites are multi-layer settlements. This change is interpreted as the development of close relations between the Late Neolithic communities and the environment, whereas the first Neolithic herders attempted to continue their pastoral tradition, sheep/goat husbandry, in spite of an environment that was ill-suited. Large game had both economic and social importance. As hunting may have had great social value for the Gumelnița communities, it is possible that the high hunting rates observed sometimes reflect collective practices. At Căscioarele, where large game played an important role, the existence of unusual practices is likely, given the exceptional character of the archaeological finds (see 2. above). This hypothesis seems unlikely at Luncavița and Vităneşti, where no exceptional structure or unusual butchery practice has been identified.

It is also possible that complex socio-economic relations existed between some of the Gumelniţa tell sites and other settlements. Some of the animal exploitation systems described may have been parts of larger economic systems. At Polgár-Csőszhalom for instance, a Late Neolithic site in Hungary, over half the animal remains from the tell are assigned to wild species, while the adjacent horizontal settlement mostly provides domestic animal remains (Schwartz in Raczky et al., 2002). Raczky et al. (2002) proposed that ritual practices took 


\section{Pastoral practices, specialization and complementary functions of the Gumelniţa sites}

This paper focuses on domestic ruminants, since cattle are the predominant domestic species during the Gumelnița period; we have observed that sheep/goats are more often in second place than pigs.

\subsection{Sheep and goats}

The kill-off patterns established for sheep and goats at Borduşani-Popină, Hârşova tell, Măriuța and Vităneşti show very similar tendencies (Fig. 8; Table 5). The main characteristic is a high proportion of animals slaughtered between six and 12 months (class C: from $37.4 \%$ 
to $58.3 \%$ of the dead animals). More generally, the age classes C and D (six months to two years) represent $59.2 \%$ to $71.4 \%$ of the animals slaughtered at these tell sites. These age classes represent animals that had attained their optimum or maximum weight, and we interpret this as animals intended for human consumption (meat type; Halstead, 1996; Helmer et al., 2007; Payne, 1973; Vigne and Helmer, 2007). These are specialized kill-off patterns. They are due to the fact that practices and strategies were the same during the whole occupation. This kind of profile is uncommon both in Europe (e.g., Greenfield, 2005; Vigne and Helmer, 2007) and in the Near East (e.g., Helmer et al., 2007) during the Neolithic and Chalcolithic periods; mixed kill-off patterns are the norm. These four sites have another common characteristic: sheep are clearly predominant over goats (see 4.3. above, Table 4). These kill-off patterns clearly show that the main product that the inhabitants of these tell sites sought for was sheep tender meat. Luncavița is different because of the lower proportion of sheep/goats slaughtered between six and 12 months (11.6\% of the dead animals; Table 5); the majority of the dead animals are adults (Fig. 8). This is a mixed kill-off pattern. Luncaviţa is the only site characterized by a more balanced representation of sheep and goats. Hârşova tell, Borduşani-Popină, Măriuța and Vităneşti were favored places for the consumption of sheep meat but we cannot propose that these animals were always raised at these settlements. Indeed, the first age classes (A and B), that is, animals aged less than six months, consist of only $0.5 \%$ to $3.1 \%$ of the dead animals at Hârşova tell, Borduşani-Popină, Măriuța and Luncavița (Table 5). Newborn lambs and kids are very fragile (Clutton-Brock and Pemberton, 2004; Dahl and Hjort, 1976; Lécrivain and Janeau, 1988), thus the very low proportions of the youngest animals observed (age class A: from $0 \%$ to $0.6 \%$ of the dead animals) are questionable. At a free-range sheep farm located in the lower French Alps (meat production), for example, the natural mortality rate for very young lambs (age class A) represents $11 \%$ of the animals that died over a period of one year (Blaise, 2006: Annex 1). Open-air sites characterized by quite high proportions of young sheep/goats are known for the Neolithic period (for example at Blagotin, Cuiry-les-Chaudardes and Halula 5; age classes A and B: from $10 \%$ to $24 \%$ of the dead animals; Greenfield, 2005; Hachem, 1995; Helmer et al., 2007).

Young sheep and goats are not absent due to differential preservation. These tell sites are well preserved, in particular Hârşova tell and Borduşani-Popină, which have produced several wooden platforms (see 3.1. above). Moreover, sieving was carried out (Table 2), so we can reject the hypothesis of differential collection. At Hârşova tell for example, although the remains from $4 \mathrm{~mm}$ sieves are included, age class A represents only $0.6 \%$ of the dead animals. 
Finally, this absence is not due to the fact that only parts of these tell sites have been

[Figure 8]

[Table 5]

\subsection{Cattle}

As there are more aurochs than cattle at Vităneşti (stage A2), and as no reliable criteria exist to discriminate these two species based on teeth, we do not provide cattle kill-off pattern for this tell site.

The four kill-off patterns established for cattle (Table 6; Fig. 9) show tendencies that are distinct from those that have been described for sheep/goats. Borduşani-Popină, Hârşova tell, Luncavița and Măriuța are characterized by mixed kill-off patterns and the youngest calves (first age class, 0-6 months) are present (from 3\% to 7\% of the dead animals). No obvious truncated profile or specialized pattern (as existed in Western Europe at the beginning of the fourth millennium BC; Bréhard et al., 2010) is observed for the four Gumelniţa settlements studied. 
[Figure 9]

[Table 6]

\subsection{Discussion}

Homogeneity of the pastoral practices developed for sheep has been observed at Hârşova tell, Borduşani-Popină, Măriuța and Vităneşti. We have shown that sheep exploitation was specialized. The main product that the inhabitants sought for was sheep tender meat. At Luncavița, the mixed profile may result from the cumulative effect of two distinct strategies for sheep and for goat exploitation. A specialization of sheep exploitation is possible but dental remains assigned to sheep are too few to confirm or refute this hypothesis. For goats, available samples are too small at each site to address this question. At least four out of the five sites studied show the same practices for sheep. These tell sites have no obvious common characteristic. Their overall animal exploitation systems clearly differ (see 3.1.2. above, Fig. 3). Moreover, they are located in different geographical areas (Fig. 1), are of different size (Table 2) and date to both Gumelniţa A2 and B1. Specialized kill-off patterns are uncommon during the Neolithic and Chalcolithic periods (see 5.1. above). Given these points, we propose that the homogeneity of the practices observed for sheep is specific to a type of settlement, the tell site.

Sheep/goat kill-off patterns published for earlier Eneolithic and Neolithic cultures are rare in Romania. Only three are available for eastern Romania; they belong to the two cultures (Hamangia and Boian) preceding the Gumelnița period. These are open-air settlements. As a species clearly dominate in each case (sheep at Techirghiol and Cheia, goats at Vlădiceasca), these three kill-off patterns do not result from the possible cumulative effect of two distinct strategies and can thus be compared to the four specialized Gumelnița kill-off patterns. Vlădiceasca and Techirghiol kill-off patterns are different from the Gumelnița profiles. At Vlădiceasca (Boian Vidra; N = 109; Bălăşescu, unpublished), it is a mixed kill-off pattern (like Luncavița, adults represent $60 \%$ of the dead animals). At Techirghiol (Hamangia; $\mathrm{N}=$ 102; Haimovici and Bălăşescu, 2006), animals were slaughtered between one and two years (age class $\mathrm{D} ; 32 \%$ of the dead animals) rather than between $6-12$ months (age class $\mathrm{C} ; 24 \%$ of the dead animals). Contrary to these two examples, the kill-off pattern established for Cheia (Hamangia; N = 240; Bălăşescu, 2008) shows tendencies similar to those observed at the four Gumelniţa sites, but the remains studied come from only one stratigraphic unit. Thus the killoff pattern established is unlikely to be representative of the overall pastoral practices of the 
settlement. The study of a more heterogeneous assemblage is essential for viable results. These three examples dated to the Early Eneolithic are characterized by distinct tendencies. Specialized exploitations similar to those observed for the Gumelnița period may have existed during the Neolithic and the Early Eneolithic, but the available examples show that these practices became the norm from the Gumelnița period only. An increase in the number of killoff patterns established from large samples (for the Neolithic and the Eneolithic) is essential to confirm this. It is difficult for the moment to propose explanations for this phenomenon given the limited information available for the Gumelniţa tell sites and their unclear function. The high homogeneity of sheep exploitation suggests however a certain standardization in pastoral practices during the Gumelniţa period. Even if it is less noticeable, kill-off patterns established for cattle show similar tendencies too (Fig. 9); the practices developed for pigs are identical at least at two of these sites (Hârşova tell and Borduşani-Popină; Bălăşescu, unpublished). Finally, as such a specialization in exploitation strategies is risky, it suggests stable and highly structured economic systems during the Gumelniţa period.

It is very likely that a part of the youngest sheep/goats are lacking at Hârşova tell, BorduşaniPopină and Luncaviţa. It implies that the first stages of sheep/goat husbandry (in particular lambing) took place mainly elsewhere and that sheep/goats were brought to these tell sites for the most part when they had reached their optimum weight (age class C) to be eaten. The available kill-off patterns would then reflect only a portion of the dead animals (truncated patterns; Bréhard et al., 2010; Halstead, 1996; Helmer et al., 2005; Stein, 1987). As the hypothesis that sheepfolds were not on the tell itself is plausible, we propose that each of these three tell sites was part of a larger pastoral system and that places or sites with complementary functions existed. Of course, pastoral functions were not as sharply contrasted as those proposed by Stein (1987) for later periods (consumer versus producer sites). Hârşova tell and Borduşani-Popină show a high consumption of animals at their optimum (and maximum) weight; the culling of adults (old breeding females, for example) also took place at these sites (adults aged more than 4 years represent $23 \%$ and $22 \%$ of the dead animals; Table 5), contrary to the "consumers site" proposed by Stein (1987). The identification of kill-off patterns complementary to those of the tell sites (characterized by higher percentages of young animals and very low proportions of sheep/goats at their optimum weight) are evidence for the existence of complementary functions during the Gumelniţa period, but the kill-off patterns described are the only ones available for the 
Gumelniţa culture. Even so, we can presume that pastoral systems functioned on a local or regional scale.

First, there could have been designated places close to the tell sites. Lambing would have taken place mainly there and the dead newborn lambs and kids would have been discarded close to the sheepfolds. For example, at Podgoritsa (a contemporary Bulgarian tell site), the identification of activity areas and built structures immediately surrounding the tell led to the conclusion that the geographic limits of a tell did not always coincide with the topographic limits of the tell's mound (Bailey, 1999; Bailey et al., 1998). Archaeological occupations have been discovered close to the Romanian tell sites but they are poorly known (data are mostly provided by surveys), their contemporaneity with the tell is not confirmed, and no archaeozoological data are available (Andreescu et al., 2001, 2003; Bem, 2007; Micu et al., 2009).

It is also possible that large pastoral systems existed on a regional scale (Bréhard et al., 2010; Halstead, 1996; Helmer et al., 2005; Stein, 1987). This second hypothesis is supported by the fact that such examples existed elsewhere in Europe in the same period. At the beginning of the fourth millennium BC in the Rhone valley (France), for example, lambing took place almost exclusively in caves, and sheep/goats were brought to large open-air settlements once they had reached their optimum weight (Bréhard et al., 2010; Helmer et al., 2005). The killoff patterns established for the three Rhone valley caves (Helmer et al., 2005) are characterized by a very high proportion of young sheep/goats (age classes A and B): from $20 \%$ to $46 \%$ of the dead animals. These caves at that time were used only for animal penning ("sheepfold-caves") and their occupation could have been seasonal (at least during lambing season). However, the situation is different, because unlike the Gumelnița tell sites, the Chassean open-air settlements were probably gathering places rather than permanent settlements. In southeastern Romania, the complementary sites could have been 'flat' sites or cave and rock shelter occupations. These kinds of settlements existed in the Gumelniţa period but they are poorly known (Boroneanţ, 2000b). Fieldwork focusing on cave occupations is being carried out in the Dobrogea region (Szmoniewski and Petcu, 2008; Voinea, 2010) but the faunal remains from the Gumelniţa levels are still too few (Popa et al., 2010). These complementary sites could have been occupied only seasonally. A part of the Gumelnița community could have moved with the flocks from the tell sites to other sites, at least during the lambing season. 


\section{Conclusion}

This research has shown that the development of a new type of settlement, the tell site, which fully began with the Gumelniţa culture, was accompanied by changes in the meat component of the diet. The homogeneity that characterized the Hamangia (phase III) and Boian cultures was followed by a greater diversity in the animal exploitation systems during the Gumelnița period. The main change is that hunting played an important role for some Gumelnița communities (the preferred species varied). However, variability existed among the domestic species as well. This may result from the interaction between several possible factors: the appearance of new husbandry techniques (Bovinae and Suinae), the development of complex socio-economic relations between the sites, a great social value given to wild mammals and a more intensive exploitation of natural resources. Environmental factors may have increased some of these changes. To understand the relations that may have existed between the sites of a given geographical zone, the characterization of the animal exploitation systems of Gumelnița sites other than tell sites is essential.

This diversity contrasts with the homogeneity of the pastoral practices developed for sheep (and, to a lesser extent, for cattle) at the Gumelniţa tell sites (five sites have been studied). We have also shown that sheep exploitation was specialized (the main product that the inhabitants sought for was tender meat). Given that this kind of specialized exploitation became the norm from the Gumelnița period, we propose that the appearance of homogeneous and specialized practices for sheep is linked to the development of a new type of settlement, the tell site. More generally, certain standardization in pastoral practices during the Gumelnița period is possible. An increase in the number of kill-off patterns established from large samples is essential to confirm this, and the publication of global archaeological studies on the Gumelnița tell sites will help to understand the homogeneity in pastoral practices. It is also very likely that a part of the youngest sheep and goats are lacking at three tell sites. This implies that the first stages of animal husbandry (lambing in particular) took place mainly elsewhere and that sheep/goats were brought to these tell sites for the most part when they had reached their optimum weight to be eaten. We suggest that these tell sites were parts of larger pastoral systems, on a local or regional scale, and that places or sites having complementary functions existed. These pastoral systems could have included places immediately surrounding the tell or the 'flat' sites and the cave and rock-shelter occupations present at that time. But these Gumelnița occupations are poorly known. Archaeological research focusing on these kinds of sites is needed to prove the existence of complementary functions (identification of kill-off patterns complementary to those of the tell sites). 


\section{References}

Andreescu, R. R., Mirea, P., Apope, Ş., 2001. Dinamica locuirilor neo-eneolitice pe valea Teleormanului. Cultură şi Civilizație la Dunărea de Jos 16-17, 29-34.

Andreescu, R. R., Mirea, P., Apope, Ş., 2003. Cultura Gumelnița în vestul Munteniei. Aşezarea de la Vităneşti, jud. Teleorman. Cercetări Arheologice XII, 71-87.

Andreescu, R. R., Lazăr, C., 2008. Valea Mostiştei. Aşezarea gumelniţeană de la SultanaMalu Roşu. Cercetări Arheologice XIV-XV, 55-76.

Arbogast, R.-M., Jacomet, S., Magny, M., Schibler, J., 2006. The significance of climate fluctuations for the lake level changes and shifts in subsistence economy during the late Neolithic (4300-2400 B.C.) in central Europe. Vegetation History and Archaeobotany 15, 403-418.

Arnold, E., Greenfield, H. J., 2006. The origins of transhumant pastoralism in temperate Southeastern Europe. A zooarchaeological perspective from the Central Balkans. BAR International Series 1538. Archaeopress, Oxford.

Bailey, D. W., 1999. What is a tell? Settlement in fifth millennium Bulgaria, in: Brück, J., Goodman, M., Making places in the prehistoric world: themes in settlement archaeology. UCL Press, London, pp. 94-111. 
Bailey, D. W., Tringham, R. E., Bass, J., Hamilton, M., Neumann, H., Stevanovic, M., Angelova, I., Raduncheva, A., 1998. Expanding the dimensions of early agricultural tells: the Podgoritsa Archaeological Project, Bulgaria. Journal of Field Archaeology 25(4), 1-24. Bălăşescu, A., 1998. Considerații preliminare asupra faunei neolitice, in: Şantierul arheologic Bucşani (Jud. Giurgiu). Raport preliminar. Campania 1998. Buletinul Muzeului Teohari Antonescu 2-4, 99-102.

Bălăşescu, A., 2000. Studiu preliminar asupra faunei descoperite la Isaccea-Suhat (cultura Boian-Giuleşti). Istro-Pontica (Muzeul tulcean la a-50-a aniversare, 1950-2000), 10-12. Bălăşescu, A., 2002. Studiul arheozoologic preliminar al faunei de mamifere descoperite pe Valea Teleormanului. Studii de Preistorie 1/2001, 59-70.

Bălăşescu, A., 2003. L'étude de la faune des mammifères découverts à Luncaviț a. PEUCE I(XIV), 453-468.

Bălăşescu, A., 2003-2004. Fauna neolitică de la Ciulniț a. Ialomiț a. Studii ș i cercetări de arheologie, istorie, etnografie ș i muzeologie IV, 257-282.

Bălăşescu, A., 2008. Consideraț ii cu privire la exploatarea mamiferelor în aș ezarea Hamangia III de la Cheia. Pontica 41, 49-56.

Bălăşescu, A., Moise, D., Dumitraşcu, V., 2003b. Mammal fauna from Borduşani-Popină, in: Popovici, D., Haită, C., Bălăşescu, A., Radu, V., Vlad, F., Tomescu, J., Archaeological pluridisciplinary researches at Borduşani-Popină. Muzeul Naț ional de Istorie a României. Seria Cercetări Pluridisciplinare VI. Editura Cetatea de Scaun, Târgovişte, pp. 103-139. Bălăşescu, A., Moise, D., Radu, V., 2005a. The palaeoeconomy of Gumelniț a communities on the territory of Romania. Cultură ș i civilizat ie la Dunărea de Jos XXII, 167-200. Bălăşescu, A., Moise, D., Radu, V., 2006. Utilisation des bovins à la traction dans le Chalcolithique de Roumanie : première approche, in: Pétrequin, P., Arbogast, R.-M., Pétrequin, A.-M., Van Willigen, S., Bailly, M. (Dir.), Premiers chariots, premiers araires : la diffusion de la traction animale en Europe pendant les $\mathrm{IV}^{\mathrm{e}}$ et $\mathrm{III}^{\mathrm{e}}$ millénaires avant notre ère. Monographie du CRA 29. CNRS Éditions, Paris, pp. 269-273.

Bălăşescu, A., Radu, V., 1999. Studiul faunei neolitice de la Siliştea-Conac (jud. Brăila). Istros IX, 197-210.

Bălăşescu, A., Radu, V., 2002. Culesul, pescuitul şi vânătoarea în cultura Boian pe teritoriul României. Studii de Preistorie 1/2001, 73-90.

Bălăşescu, A., Radu, V., 2002-2003. Studiul arheozoologic preliminar al materialului faunistic de la Cheia (jud. Constanța). Campania 2001. Pontica 35-36, 25-32. 
Bălăşescu, A., Radu, V., 2003. Studiul materialului faunistic descoperit în Tell-ul de la Vităneș ti (Jud. Teleorman) : nivelul Gumelniț a B1. Cercetări Arheologice XII, 363-383.

Bălăşescu, A., Radu, V., 2004. Omul şi animalele. Strategii şi resurse la comunităț ile Hamangia şi Boian. Muzeul Naţional de Istorie a României, Seria Cercetări Pluridisciplinare IX. Editura Cetatea de Scaun,Târgoviș te.

Bălăşescu, A., Radu, V., Moise, D., 2005b. Omul şi mediul animal între mileniile VII-IV î.e.n. la Dunărea de Jos. Muzeul Național de Istorie a României, Seria Cercetări Pluridisciplinare XI. Editura Cetatea de Scaun, Târgovişte.

Bălăşescu, A., Radu, V., Nicolae, C., 2003c. Fauna de la Chitila-Fermă. Studiu arheozoologic preliminar. Materiale de Istorie şi Muzeografie XVII, 3-10.

Bălăşescu, A., Udrescu, M., 2005. Matériaux ostéologiques du site énéolithique (niveau Boian, phase Vidra) de Vlădiceasca-Valea Argovei, dép. Călăraşi. Studii de Preistorie 2, 115134.

Bălăşescu, A., Udrescu, M., Radu, V., Popovici, D., 2003a. Archéozoologie en Roumanie. Corpus de données. Muzeul Național de Istorie a României, Seria Cercetări Pluridisciplinare V. Editura Cetatea de Scaun,Târgovişte.

Bartosiewicz, L., 2005. Plain talk: animals, environment and culture in the Neolithic of the Carpathian Basin and adjacent areas, in: Bailey, D., Whittle, A., Cummings, V. (Eds.), (un)settling the Neolithic. Oxbow Books, Oxford, pp. 51-63.

Bartosiewicz, L., Van Neer, W., Lentacker, A., 1997. Draught cattle: their osteological identification and history. Annales des Sciences Zoologiques 281. Musée royal de l'Afrique centrale, Tervuren.

Bem, C., 2001. Noi propuneri pentru o schiț ă cronologică a eneoliticului românesc. Pontica $33-34,25-121$.

Bem, C. (Ed.), 2007. Repertoriul Microzonei Bucşani. Muzeul Naţional de Istorie a României, Bucureşti.

Blaise, E., 2006. Référentiel actuel de brebis « Préalpes du Sud» (Digne, Alpes-de-HauteProvence, France) : pratiques d'élevage et âges dentaires. Anthropozoologica 41(2), 191-214. Boessneck, J., Muller, H., Teichert, M., 1964. Osteologische Unterscheidungsmerkmale zwischen Schaf (Ovis aries) und Ziege (Capra hircus). Kühn Archiv 78, 1-129.

Bökönyi, S., 1972. Aurochs (Bos primigenius Boj.) remains from the Orjeg peat-bogs between the Danube and Tizsa rivers. Cumania, 17-56.

Bökönyi, S., Bartosiewicz, L., 1997. Tierknochenfunde, in: Hiller, S., Nikolov, V. (Eds.), Karanovo. Die Ausgrabungen im Sudsektor 1984-1992, band I. Verlag Ferdinand 
Berger \& Söhne, Horn/Wien, Salzburg-Sofia, pp. 385-423.

Bolomey, A., 1966. Fauna neolitică din aşezarea Boian A de la Vărăşti. Studii şi Cercetări de Antropologie 3(1), 27-34.

Bolomey, A., 1981. Contribuție la cunoaşterea economiei animale a culturii Boian în lumina materialelor de la Căscioarele, jud. Călăraşi. Cercetări Arheologice 5, 169-193.

Bølviken, E., Helskog, E., Helskog, K., Holm-Olsen, I. M., Solheim, L., Bertelsen, R., 1982. Correspondence Analysis: An Alternative to Principal Components. World Archaeology 14(1), 41-60.

Boroneanț, V., 2000a. Chitila-Fermă. Studiu Monografic. I. Istoricul cercetărilor. Materiale de Istorie şi Muzeografie 14, 49-54.

Boroneanţ, V., 2000b. Arheologia peşterilor şi minelor din România. cIMeC - Institutul de Memorie Culturală, Bucureşti.

Brain, C.K., 1981. The Hunters or the Hunted? An Introduction to African Cave Taphonomy. The University of Chicago Press, Chicago and London.

Bréhard, S., Beeching, A., Vigne, J.-D., 2010. Shepherds, cowherds and site function on middle Neolithic sites of the Rhône valley: An archaeozoological approach to the organization of territories and societies. Journal of Anthropological Archaeology 29(2), 179188.

Cârciumaru, M., 1996. Paleoetnobotanica. Studii în Preistoria şi Protoistoria României. Istoria agriculturii din România. Editura Glasul Bucovinei Helios, Iaș i.

Carozza, J.-M., Micu, C., Mihail, F., Carozza, L., In press. Landscape change and archaeological settlements in the lower Danube valley and delta from early Neolithic to Chalcolithic time: A review. Quaternary International (doi:10.1016/j.quaint.2010.07.017). Cavaleriu, R., Bejenaru, L., 2009. Cercetări arheozoologice privind cultura Cucuteni, faza A. Editura Universitatea Alexandru Ioan Cuza, Iaşi.

Chapman, J., 2010. Houses, Households, villages, and Proto-Cities in southeastern Europe, in: Anthony, D. W. (Ed.), The Lost World of Old Europe: The Danube Valley, 5000-3500 BC. New York: The Institute for the Study of the Ancient World. Princeton University Press, Princeton and Oxford, pp. 74-89.

Chapman, J., Higham, T., Slavchev, V., Gaydarska, B., Honch, N., 2006. The social context of the emergence, development and abandonment of the Varna cemetery, Bulgaria. European Journal of Archaeology 9(2-3), 159-183.

Clouse, R. A., 1999. Interpreting Archaeological Data through Correspondence Analysis. Historical Archaeology 33(2), 90-107. 
Clutton-Brock, J., Dennis-Bryan, K., Armitage, P. L., 1990. Osteology of the Soay sheep.

Bulletin British Museum (Natural History) Zoology Series 56(1), 1-56.

Clutton-Brock, T., Pemberton, J., 2004. Soay Sheep. Dynamics and Selection in an Island Population. Cambridge University Press, Cambridge.

Comşa, E., 1990. Complexul neolitic de la Radovanu. Cultură ș i civilizaț ie la Dunărea de Jos VIII. Muzeul Dunării de Jos, Călăraș i.

Comşa, E., 1996. Viața oamenilor din spaț iul Carpato-Danubiano-Pontic în mileniile 7-4 î. Hr. EDP, Bucureşti.

Cucchi, T., Bălăşescu, A., Bem, C., Radu, V., Vigne, J.-D., Tresset, A., 2011. New insights into the invasive process of the eastern house mouse (Mus musculus musculus) in Europe: evidences from the burnt houses of Chalcolithic Romania. The Holocene 21(8), 1195-1202. Dahl, G., Hjort, A., 1976. Having Herds. Pastoral Herd Growth and Household Economy. Stockholm Studies in Social Anthropology. University of Stockholm, Stockholm.

Degerbøl, M., Fredskild, B., 1970. The urus (Bos primigenius Bojanus) and the Neolithic domesticated cattle (Bos taurus domesticus Linné) in Denmark. Zoological and palynological investigations. Det Kongelige Danske Videnskabernes Selskab, Biologiske skrifter 17(1). Ed. Munksgaards Forlag, København.

Ducos, P., 1968. L'origine des animaux domestiques en Palestine. Publications de l'Institut de Préhistoire de l'Université de Bordeaux 6. Éditions Masson, Paris.

Dumitrescu, V., 1965. Principalele rezultate ale primelor două campanii de săpături din aşezarea neolitică târzie de la Căscioarele. Studii şi Cercetări de Istorie Veche 16(2), 215237.

Dumitrescu, V., Bolomey, A., Mogoşanu, F., 1983. Esquisse d'une préhistoire de la Roumanie (jusqu'à la fin de l'Âge du Bronze). Editura Ştiințifică şi Enciclopedică, Bucureşti. Dumitrescu, V., Vulpe, A., 1988. Dacia înainte de Dromihete. Editura Ştiinţifică şi Enciclopedică, Bucureşti.

Ellis, L., 1984. The Cucuteni-Tripolye culture: Study in technology and the origins of complex society. BAR International Series 217. Archaeopress, Oxford.

El Susi, G., 1996. Vânători, pescari şi crescători de animale în Banatul mileniilor VI î.Ch-I d.Ch. Studiu arheozoologic. Editura Mirton, Timişoara.

El Susi, G., 2002. Archaeozoological researches in the eneolithical site from Drăgăneşti-Olt (Slatina Olt county). Cultură şi Civilizație la Dunărea de Jos XIX, $154-158$.

Greenfield, H. J., 2005. A reconsideration of the secondary products revolution in south- 
eastern Europe: on the origins and use of domestic animals for milk, wool, and traction in the central Balkans, in: Mulville, J., Outram, A. K. (Eds.), The Zooarchaeology of Fats, Oils, Milk and Dairying. Proceedings of the 9th Conference of the International Council of Archaeozoology (Durham, 2002). Oxbow Books Ltd, Oxford, pp. 14-31.

Greenfield, H. J., 2008. Faunal assemblages from the Early Neolithic of the central Balkans: methodological issues in the reconstruction of subsistence and land use, in: Bonsall, C., Boroneanț, V., Radovanović, I. (Eds.), The Iron Gates in Prehistory: New perspectives. BAR International Series 1893. Archaeopress, Oxford, pp. 103-114.

Guilaine, J. (Dir.), 1998. Sépultures d'Occident et genèses des mégalithismes (9000-3500 avant notre ère). Éditions Errance, Paris.

Guilaine, J. (Dir.), 2007. Le Chalcolithique et la construction des inégalités. Tome 1, Le continent européen. Paris: Éditions Errance, Paris.

Hachem, L. 1995. La faune rubanée de Cuiry-lès-Chaudardes (Aisne, France). Essai sur la place de l'animal dans la première société néolithique du Bassin parisien. Thèse de doctorat, Université Paris 1, Panthéon-Sorbonne (unpublished $\mathrm{PhD}$ thesis).

Haimovici, S., 1987. Unele date cu privire la un lot de faună descoperit în aşezarea eponimă de la Hamangia (Baia). Pontica 20, 43-52.

Haimovici, S., 1996. Studiul arheozoologic al materialului provenit din staţiunea gumelnițeană de la Carcaliu. PEUCE 12, 377-392.

Haimovici, S., Bălăşescu, A., 2006. Zooarchaeological study of the faunal remains from Techirghiol (Hamangia culture, Dobrogea, Romania). Cercetări Arheologice XIII, 371-391. Halstead, P., 1996. Pastoralism or household herding? Problems of scale and specialization in early Greek animal husbandry. World Archaeology 28(1), 20-42.

Haită, C., 2000. Sédimentologie, in: Popovici, D., Randoin, B., Ryalland, Y., Voinea, V., Vlad, V., Bem, C., Bem, C., Haită, G., Les recherches archéologiques du tell de Hârşova (dép. de Constanța) 1997-1998. Cercetări Arheologice XI(1), pp. 48-55.

Haită, C., 2001. Studiul micromorfologic asupra spaţiilor amenajate din interiorul locuinţelor din siturile eneolitice Hârşova-tell (jud. Constanţa) şi Borduşani-Popină (jud. Ialomiţa). Cultură şi Civilizaţie la Dunărea de Jos XVI/XVII, 48-52.

Haită, C., 2002. Preliminary considerations on a sedimentary sondage performed on the Eneolithic tell from Bucşani. Studii de Preistorie 1/2001, 131-145.

Haită, C., 2003. Micromorphology. Inhabited space disposition and uses. Analysis of an occupation zone placed outside the dwellings, in: Popovici, D., Haită, C., Bălăşescu, A., Radu, V., Vlad, F., Tomescu, J., Archaeological pluridisciplinary researches at Borduşani- 
Popină. Muzeul Naț ional de Istorie a României. Seria Cercetări Pluridisciplinare VI. Editura Cetatea de Scaun, Târgovişte, pp. p. 50-74.

Haită, C., 2005. Preliminary considerations on the sedimentological sondages performed in the neo-eneolithic tell Borduşani Popină. Cultură şi Civilizaţie la Dunărea de Jos XXII, 151160 .

Haită, C., Radu, V., 2003. Les zones de rejets menageres de la culture Gumelnița : témoins dans l'évolution chrono-stratigraphique des tells. Etude micromorphologique et archéoichthyologique sur le tell d'Hârşova (Dep. Constanța). Cercetări Arheologice XII, 387-403. Halstead, P., Collins, P., Isaakidou, V., 2002. Sorting the sheep from the goats: morphological distinctions between the mandibles and the mandibular teeth of adult Ovis and Capra. Journal of Archaeological Science 29, 545-553.

Haşotti, P., 1997. Epoca neolitică în Dobrogea. Bibliotheca Tomitana, Constanţa.

Helmer, D., 1995. Biometria i arqueozoologia a partir d'alguns exemples del Proxim Orient. Cota Zero 11, 51-60.

Helmer, D., 2000. Discrimination des genres Ovis et Capra à l'aide des prémolaires inférieures 3 et 4 et interprétation des âges d'abattages: l'exemple de Dikili Tash (Grèce). Anthropozoologica 31, 29-38.

Helmer, D., Gourichon, L., Sidi Maamar, H., Vigne, J.-D., 2005. L'élevage des caprinés néolithiques dans le sud-est de la France : saisonnalité des abattages, relations entre grottesbergeries et sites de plein air. Anthropozoologica 40(1), 167-189.

Helmer, D., Gourichon, L., Vila, E., 2007. The development of the exploitation of products from Capra and Ovis (meat, milk and fleece) from the PPNB to the Early Bronze in the northern Near East (8700 to 2000 BC cal.). Anthropozoologica 42(2), 41-69.

Higham, C. F. W., 1967. Stock rearing as a cultural factor in prehistoric Europe. Proceedings of the Prehistoric Society 33, 84-106.

Johannsen, N. N., 2006. Draught cattle and the South Scandinavian economies of the $4^{\text {th }}$ millennium BC. Environmental Archaeology 11(1), 35-48.

Lécrivain, E., Janeau, G., 1988. Mortalité néonatale d'agneaux nés en plein air sans aide de l'éleveur. INRA Productions Animales 1(5), 331-338.

Lichardus, J., Lichardus-Itten, M., Bailloud, G., Cauvin, J., 1985. La Protohistoire de l'Europe. Le Néolithique et le Chalcolithique entre la Méditerranée et la mer Baltique. Presses Universitaires de France, Paris. 
Ludwig, A., Pruvost, M., Reissmann, M., Benecke, N., Brockmann, G. A., Castaños, P., Cieslak, M., Lippold, S., Llorente, L., Malaspinas, A.-S., Slatkin, M., Hofreiter, M., 2009. Coat color variation at the beginning of horse domestication. Science 324(5926), 485. Manhart, H., 1998. Die vorgeschichtliche Tierwelt von Koprivec und Durankulak und anderen prähistorischen Fundplatzen in Bulgarien aufgrung von Knochenfunden aus archäologischen Ausgrabungen. Documenta naturae 116.

Manolakakis, L., 2007. Varna et le Chalcolithique de Bulgarie, in: Guilaine, J. (Dir.), Le Chalcolithique et la construction des inégalités. Tome 1, Le continent européen. Éditions Errance, Paris, pp. 23-46.

Marinescu-Bîlcu, S., 2001. O civilizație necunoscută: Gumelnița. Colecția Patrimoniu Cultural. cIMeC - Institutul de Memorie Culturală, Bucureşti.

Marinescu-Bîlcu, S., 2002. A few observations on the internal organization of Gumelnița communities on Lake Cătălui islet. Cultură şi Civilizație la Dunărea de Jos XIX, 149-150. Marinescu-Bîlcu, S., Bolomey, A., 2000. Drăguşeni. A Cucutenian community. Editura Enciclopedică, Bucureşti. Wasmuth Verlag, Tübingen.

Micu, C., 2005. Neo-eneoliticul în Nordul Dobrogei în lumina cercetărilor de la Isaccea şi Luncavița. Teză de doctorat, Institutului de Arheologie V. Pârvan, Bucureşti.

Micu, C., Mihail, F., Carozza, L., Florea, M., 2009. Cateva observatii asupra unor situri eneolitice din zona de nord a Dobrogei. Peuce S.N. VII, 9-48.

Moise, D., 1997. Mammals, in: Marinescu Bîlcu, S. (Dir.), Archaeological researches at Borduşani-Popina (Ialomița county). Preliminary report 1993-1994. Cercetări Arheologice X, $110-127$.

Moise, D., 1999. Studiul materialului faunistic aparţinând mamiferelor, descoperit în locuințele gumelnițene de la Însurăței-Popina I (Jud. Brăila). Istros IX, 171-190.

Moise, D., 2000. Etude du matériel ostéologique appartenant aux mammifères découvert dans le Complexe 521 (la zone ménagère) sur le tell néoénéolithique de Hârşova (dép. de Constantza). Cercetări Arheologice XI(1), 84-111.

Moise, D., 2001a. Studiul materialului osteologic de mamifere, in: Marinescu-Bîlcu, S. (Dir.), Aşezarea eneolitică de pe insula „La Ostrov”, Lacul Taşaul (Năvodari, jud. Constanța). Raport preliminar - Campaniile 1999-2000. Pontica 33-34, 156-164.

Moise, D., 2001b. Studiul materialului faunistic provenit din aşezarea neolitică de la Măriuţa. Cultură şi Civilizație la Dunărea de Jos XVI-XVII, 207-222. 
Monah, D., Dumitroaia, G., Monah, F., Preuteasa, C., Munteanu, R., Nicola, D., 2003.

Poduri-Dealul Ghindaru. O troie în Subcarpații Moldovei. Bibliotheca Memoriae Antiquitatis

8. Editura Constantin Matasa, Piatra-Neamț.

Monah, F., 2000. Rapport préliminaire sur les macrorestes végétaux du complexe ménager 521 - le tell énéolithique Hârș ova (dép. Constanț a). Campagne 1998. Cercetări Arheologice $\mathrm{XI}(1), 66-74$.

Neagu, M., 2003. Neoliticul mijlociu la Dunărea de Jos. Cultură şi civilizaţie la Dunărea de Jos 20. Editura Daim, Călăraşi.

Necrasov, O., 1973. Studiul resturilor de faună din aşezarea neolitică de la Radovanu, jud. Ilfov. Materiale şi Cercetări Arheologice 10, 39-46.

Necrasov, O., Gheorghiu, S., 1970. Studiul resturilor de faună din aşezarea neolitică de la Izvoarele. Materiale şi Cercetări Arheologice 9, 91-96.

Necrasov, O., Haimovici, S., 1959. Fauna din complexele Boian de lângă satul Bogata. Materiale şi Cercetări Arheologice 5, 127-130.

Necrasov, O., Haimovici, S., 1966. Studiul resturilor de faună neolitică descoperite în stațiunea Gumelnița. Studii şi Cercetări de Istorie Veche XVII(1), 101-108.

Nica, M., Schuster, C., Zorzoliu, T., 1995. Cercetări arheologice în tell-ul gumelnițeanosălcuțean de la Drăgăneşti-Olt, punctul “Corboaica” - campaniile din anii 1993-1994.

Cercetări arheologice în aria nord-tracă 1, 9-46.

Pandrea, S., 2000. Câteva observații referitoare la periodizarea culturii Boian. Istros X, 35-70.

Pandrea, S., Vernescu, M., Stoian, V., Croitoru, C., 2009. Cercetările arheologice din aşezarea Gumelniţa A1 de la Însurăței - "Popina II" (2002 -2005). Istros XV, 291-318.

Parkinson, W. A., Yerkes, R. W., Gyucha, A., Sarris, A., Morris, M., Salisbury, R. B., 2010. Early Copper Age Settlements in the Körös Region of the Great Hungarian Plain. Journal of Field Archaeology 35(2), 164-183.

Parnic, V., Oprea, V., Dobre, G., 2002. Contribuții la repertoriul arheologic al județului Călăraşi. Descoperiri gumelnițene pe valea Mostiştei. Studii de Preistorie 1/2001, 193-208. Payne, S., 1973. Kill-off patterns in sheep and goats: the mandibles from Asvan Kale. Anatolian Studies 23, 281-303.

Payne, S., 1985. Morphological distinctions between the mandibular teeth of young sheep, Ovis and goats, Capra. Journal of Archaeological Science 12, 139-147.

Petrescu-Dâmbovița, M., 2001. Eneoliticul dezvoltat, in: Petrescu-Dâmbovița, M., Vulpe, A. (Coord.), Istoria românilor. Vol.1: Moș tenirea timpurilor Îndepărtate. Bucureşti, pp. 154169. 
Petrescu-Dâmbovița, M., Vulpe, A. (Coord.), 2001. Istoria românilor, Vol.1: Moştenirea timpurilor îndepărtate. Bucureşti.

Popa, E., Radu, V., Bălăşescu, A., 2010. Fauna din Peştera „La Baba”, in: Cronica Cercetărilor Arheologice din România, Campania 2009. cIMeC - Institutul de Memorie Culturală, Bucureşti, pp. 56-57.

Popa, E., Radu, V., Bălăşescu, A., 2011. Studiul materialului faunistic eneolitic, in: Frânculeasa, A., Seciu - județ ul Prahova, un sit din epoca neo-eneolitică în nordul Munteniei. Editura Oscar Print, Ploieș ti, pp. 73-84.

Popovici, D., 2010. Copper Age Traditions North of the Danube River, in: Anthony, D. W. (Ed.), The Lost World of Old Europe: The Danube Valley, 5000-3500 BC. New York: The Institute for the Study of the Ancient World. Princeton University Press, Princeton and Oxford, pp. 90-111.

Popovici, D., Haită, C., Bălăşescu, A., Radu, V., Vlad, F., Tomescu, J., 2003. Archaeological pluridisciplinary researches at Borduș ani-Popina. Muzeul Naț ional de Istorie a României. Seria Cercetări Pluridisciplinare VI. Editura Cetatea de Scaun, Târgoviș te.

Popovici, D., Randoin, B., Rialland, Y., 2001. Le tell néolithique et chalcolithique d'Hârşova (Roumanie), in: Guilaine, J. (Ed.), Communautés villageoises du Proche-Orient à l'Atlantique (8000-2000 avant notre ère). Éditions Errance, Paris, pp. 119-152.

Popovici, D., Randoin, B., Rialland, Y., Voinea, V., Vlad, F., Bem, C., Bem, C., Haită, G., 2000. Les recherches archéologiques du tell de Hârşova (dép. de Constanța) 1997-1998.

Cercetări Arheologice XI(1), 13-123.

Prummel, W., Frisch, H.-J., 1986. A guide for the distinction of species, sex and body side in bones of sheep and goat. Journal of Archaeological Science 13, 567-577.

Raczky, P., Meier-Arendt, W., Anders, A., Hajdu, Zs., Nagy, E., Kurucz, K., Domboroczki, L., Sebok, K., Sumegi, P., Magyari, E., Szanto, Zs., Gulyas, S., Dobo, K., Bacskay, E., T. Biro, K., Schwartz, Ch., 2002. Polgár-Csőszhalom (1989-2000): summary of the HungarianGerman excavations on a Neolithic settlement in Eastern Hungary, in: Aslan, R., Blum, S., Kastl, G., Schweizer, F., Thum, D. (Eds.), Mauerschau: Festschrift für Manfred Korfmann. Remshalden-Grunbach, Greiner, pp. 833-860.

Renfrew, C., 1978. Varna and the social context of early metallurgy. Antiquity 52, 199-203. Rowley-Conwy, P., 1991. Arene Candide: a small part of a larger pastoral system. Rivista di Studi Liguri A LVII(1-4), 95-116. 
Schibler, J., Jacomet, S., 2010. Short climatic fluctuations and their impact on human foreland. Environmental Archaeology 15, 173-182.

Şerbănescu, D., Trohani, G., 1978. Cercetările arheologice pe Valea Mostiştea, in: Vrabie, V. (Ed.), Ilfov. File de Istorie. Romanian Popular Republic Academic Press, Bucharest, pp. 1832.

Slavchev, V. (Ed.), 2008. The Varna Eneolithic necropolis and problems of Prehistory in southeast Europe. Studia in memoriam Ivani Ivanov. Acta Musei Varnaensis VI. Musei Varnaensis, BapHa.

Smith, A., Munro, N. D., 2009. A Holistic Approach to Examining Ancient Agriculture: A Case Study from the Bronze and Iron Age Near East. Current Anthropology 50(6), 925-936. Stein, G., 1987. Regional economic integration in early state: 3rd millennium BC pastoral production at Gritille, southeast Turkey. Paléorient 13(2), 101-111.

Ştirbu, M., 1980. Paleofauna neolitică de la Radovanu şi unele aspecte ale ocupațiilor locuitorilor din cultura Boian. Analele Ştiințifice ale Universității Al. I. Cuza 26, s. II, a. Biologie, 107-108.

Stuiver, M., Reimer, P. J., 1993, Extended ${ }^{14} \mathrm{C}$ data base and revised CALIB $3.0{ }^{14} \mathrm{C}$ age calibration program. Radiocarbon 35, 215-230.

Szmoniewski, B., Petcu, R., 2008. Preliminary report from the new excavation in Peştera Baba (Baba Cave), Grădina, dpt Constanța. Pontica 41, 35-47.

Todorova, H., 1978. The Eneolithic Period in Bulgaria in the Fifth Millennium B.C. BAR International Series 49. B.A.R., Oxford.

Tomescu, M., 2000. Holocenul - Date cronologice şi climatice. Cercetări Arheologice 11(1), 235-270.

Ursulescu, N., 1998. Inceputurile istoriei pe teritoriul Romaniei. Casa Editorială Demiurg, Iaşi.

Vigne, J.-D., 1988. Les mammifères du Post-Glaciaire de Corse, étude archéozoologique. Gallia Préhistoire $26^{\text {ème }}$ supplément. Éditions CNRS, Paris.

Vigne, J.-D., Helmer, D., 2007. Was milk a "secondary product" in the Old World neolithisation process? Its role in domestication of cattle, sheep and goats. Anthropozoologica 42(2), 9-40.

Voinea, V., 2004-2005. Cauze privind sfầrşitul eneoliticului în zona litoralului vest-pontic. Aşezarea de pe insula „La Ostrov”, Lacul Taşaul (Năvodari, jud. Constanţa). Pontica 37-38, 21-46. 
Voinea, V., 2005. Ceramica complexului cultural Gumelniţa-Karanovo VI. Fazele A1 si A2. Muzeul de Istorie Naţională şi Arheologie Constanța. Editura Ex Ponto, Constanţa.

Voinea, V., 2010. Cheia, com. Grădina jud. Constanţa Punct: Vatra satului, Peştera La Izvor, Peştera La Baba, Peştera X, in: Cronica Cercetărilor Arheologice din România, Campania 2009. cIMeC - Institutul de Memorie Culturală, Bucureşti, pp. 54-57.

Voinea, V., Neagu, G., 2008. Archaeological research at Hamangia III settlement from Cheia (2004-2008). Pontica 41, 9-34.

Zeder, M. A., Pilaar, S. E., 2010. Assessing the reliability of criteria used to identify mandibles and mandibular teeth in sheep, Ovis, and goats, Capra. Journal of Archaeological Science 37(2), 225-242.

\section{Figure caption list}

Fig. 1. Geographical distribution (in light grey) of the main Eneolithic cultures in southeastern Romania (Hamangia, Boian and Gumelnița), and location of the 29 Romanian sites included in the study. 1: Drăgăneşti-Olt; 2: Lăceni-Măgura; 3: Vităneşti; 4: Izvoarele; 5: Bucşani; 6: Chitila; 7: Seciu; 8: Măriuța; 9: Şeinoiu; 10: Tangâru; 11: Căscioarele; 12: Radovanu; 13: Vlădiceasca; 14: Sultana; 15: Vărăşti; 16: Gumelnița; 17: Bogata; 18: Ciulnița; 19: BorduşaniPopină; 20: Însurăței; 21: Siliştea-Conac; 22: Carcaliu; 23: Luncavița; 24: Isaccea; 25 :

Hârşova tell; 26: Hamangia; 27: Cheia; 28: Năvodari; 29: Techirghiol. See table 1 and 2 for details. Map after Bălăşescu et al. 2005a. 
Fig. 2. Comparaison of the faunal spectra between Hamangia (phase III), Boian and

Fig. 3. Plot of the correspondence analysis including Boian, Hamangia and Gumelnița faunal assemblages, factor axes 1 and 2 (see table 3 for details and text, 3.2.2., for explanation of the methodology). The names of the most reliable assemblages are in bold type (see the text, 3.1.1., for explanation). The Boian and Hamangia assemblages are in grey; the latter are underlined. The size of the symbols for the eight variables is proportional to their contribution to factors 1 and 2 .

Fig. 4. Plot of the correspondence analysis including Boian, Hamangia and Gumelnița faunal assemblages, factor axes 1 and 3 (see table 3 for details and text, 3.2.2., for explanation of the methodology). The names of the most reliable assemblages are in bold type (see the text, 3.1.1., for explanation). The Boian and Hamangia assemblages are in grey; the latter are underlined. The size of the symbols for the eight variables is proportional to their contribution to factors 1 and 2.

Fig. 5. Comparaison of the faunal spectra between the nine Gumelnița assemblages with high hunting rates. Only the main wild mammals are included. See table 3 for the complete names of the tell sites. The number of identified specimens (NISP) is given in parentheses. The names of the most reliable assemblages are in bold type (see the text, 3.1.1., for explanation).

Fig. 6. Same plot than in figure 3, but data coming from eleven distinct archaeological structures (table 3) have been added as supplementary objects (the names are in italic type). 
And only the names of the five Gumelniţa sites that provided these detailed faunal spectra are given. See the text (3.1.1.) to have details on the archaeological structures.

Fig. 7. Relationship between assemblage size (number of identified wild mammal specimens, NISP) and number of species of wild mammals based on the Hamangia, Boian and Gumelniţa faunal assemblages in Romania (see table 3 for details). Logarithm is used to overcome the high variability in sample sizes (from 13 NISP to 5989). A trend line is added $(y=0.2212 \mathrm{x}+$ $\left.0.4541 ; \mathrm{R}^{2}=0.772\right)$.

Fig. 8. Sheep/goat kill-off patterns for the five Gumelniţa tell sites selected for the study (see table 5 for details). See the text (3.2.3.) for explanation of the methodology. Sheep are predominant, except at Luncavița (in grey), where there is a more balanced representation of sheep and goats. As the age classes used are not the same length, the histograms of relative frequencies are corrected according to the size of the time bracket of each age class. The minimum number of individuals (MNI) is given in parentheses.

Fig. 9. Cattle kill-off patterns for the four Gumelnița tell sites selected for the study (see table 6 for details). See the text (3.2.3.) for explanation of the methodology. As the age classes used are not the same length, the histograms of relative frequencies are corrected according to the size of the time bracket of each age class. The minimum number of individuals (MNI) is given in parentheses. 


\section{Tables with captions}

Table 1

Eneolithic cultures from southeastern Romania, and chronological data. The radiocarbon

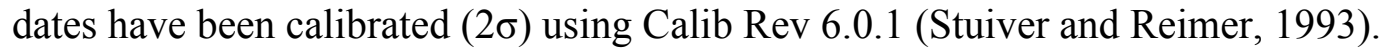

\begin{tabular}{|c|c|c|c|c|}
\hline Culture & Stage & Chronological limits & Region & Lab dating $(B P) ; 2 \sigma$ calibrated age (cal $B C)$ \\
\hline HAMANGIA & & (Beginning 5th mill. BC) & Dobrogea & $6020 \pm 43 ; 5020-4797$ (Cheia) a \\
\hline BOIAN & Giuleşti & i & Muntenia and Dobrogea & 5797 \pm 43 (UBA-7793); $4730-4540$ (Ciulnița) \\
\hline \multirow[t]{2}{*}{$5000-4450 \mathrm{cal} \mathrm{BC}$} & Vidra & 1 & Muntenia & l \\
\hline & Spanțov & $(4800-4450 \mathrm{cal} \mathrm{BC})$ & Muntenia and Dobrogea & $\begin{array}{l}5774 \pm 28 \text { (UBA-9631); } 4702-4547 \text { (Hârşova) } \\
5850 \pm 70 ; 4852-4537 \text { (Radovanu) b } \\
5750 \pm 80 ; 4790-4447 \text { (Căscioarele) b } \\
5705 \pm 80 ; 4715-4368 \text { (Căscioarele) b } \\
5780 \pm 65 ; 4785-4489 \text { (Căscioarele) b }\end{array}$ \\
\hline \multirow{11}{*}{$\begin{array}{l}\text { GUMELNIȚA } \\
4600 / 4500-3500 \mathrm{cal} \mathrm{BC}\end{array}$} & Al & I & Muntenia and Dobrogea & $5620 \pm 50 ; 4543-4354$ (Isaccea) b \\
\hline & & & & $5575 \pm 65 ; 4544-4328$ (Hârşova) b \\
\hline & $\mathrm{A} 2$ & (4350-4000 cal BC) & Muntenia and Dobrogea & $5425 \pm 40 ; 4353-4229$ (Luncavița) c \\
\hline & & & & $\begin{array}{l}5380 \pm 45 ; 4336-4055 \text { (Hârşova tell) b } \\
5304 \pm 51 ; 4261-4034 \text { (Hârşova tell) b }\end{array}$ \\
\hline & & & & $5382 \pm 43$ (UBA-7791); $4336-4057$ (Hârşova) \\
\hline & & & & 5461 \pm 42 (UBA-7792); 4369-4235 (Hârşova) \\
\hline & & & & 5379 \pm 27 (UBA-9632); $4331-4164$ (Vităneşti) \\
\hline & & & & $5430 \pm 40 ; 4354-4231$ (Vităneşti) d \\
\hline & & & & 5400土40; 4343-4162 (Vităneşti) d \\
\hline & B1 & $(3670-3500$ cal BC) & Muntenia & 4785 $\pm 43 ; 3651-3511$ (Bucşani) e \\
\hline & & & & $\begin{array}{l}4758 \pm 26 \text { (UBA-9633); } 3637-3516 \text { (Vităneşti) } \\
4820+40 \cdot 3667-3520\end{array}$ \\
\hline
\end{tabular}

a: Voinea and Neagu, 2008; b: Bem, 2001; c: Micu, 2005; d: Ludwig et al., 2009; e: Cucchi et al., 2011; others radiocarbon dates are from the Chronobos project (Tresset, personal communication 2011). 
Table 2

Romanian archaeological sites included in the study. na: data not available; Gum: Gumelnița; BV: Boian Vidra.

\begin{tabular}{|c|c|c|c|c|c|c|c|}
\hline Site & Region & $\begin{array}{l}\text { Eneolithic } \\
\text { culture(s) }\end{array}$ & Tell size & Tell stratigraphic data & $\begin{array}{l}\text { Culture (and stage) with an } \\
\text { archaeozoological study }\end{array}$ & Sieving & Faunal remains come from \\
\hline Cheia * & Dobrogea & Hamangia & & & Hamangia III & $\mathrm{x}$ (partial) & Dwellings and pits \\
\hline Hamangia & Dobrogea & Hamangia & & & Hamangia III & & na ("cultural level") \\
\hline Techirghiol & Dobrogea & Hamangia & & & Hamangia III & & Pits \\
\hline Isaccea * & Dobrogea & Boian & & & Boian Giulești & $\mathrm{x}$ (partial) & Dwellings and pits \\
\hline Bogata & Muntenia & Boian & & & Boian Giuleşti & & Pits \\
\hline Ciulnița & Muntenia & Boian & & & Boian Giuleşti & & Dwellings and pits \\
\hline Siliştea-Conac & Muntenia & Boian & & & Boian Giuleşti & & Pits \\
\hline Lăceni-Măgura & Muntenia & Boian & & & Boian Giulești, Spanțov & $\mathrm{x}$ (extensive) & na ("cultural level") \\
\hline Vărăşti & Muntenia & Boian & & & Boian Vidra & & Pits \\
\hline Izvoarele & Muntenia & Boian & & & Boian Spanțov & & na ("cultural level") \\
\hline Vlădiceasca & Muntenia & Boian; Gumelnița & $40 \times 80 \mathrm{~m}$ & $\begin{array}{l}3.8-4.2 \mathrm{~m} \text { in height }(2 \mathrm{~m} \mathrm{BV} ; 1.8-2.2 \mathrm{~m} \\
\text { Gum) }\end{array}$ & Boian Vidra; Gumelnița A1, A2, B1 & & na ("cultural level") \\
\hline Radovanu & Muntenia & Boian; Gumelnița & $50 \times 70 \mathrm{~m} ; 3500 \mathrm{~m} 2$ & $1.6 \mathrm{~m}$ in height (Boian+Gum) & Boian Spanțov & & na ("cultural level") \\
\hline Căscioarele & Muntenia & Boian; Gumelnița & $57 \times 103 \mathrm{~m}$ & $\begin{array}{l}5 \mathrm{~m} \text { in height }(1.4 / 1.8 \mathrm{~m} \text { Boian; } \sim 3 \mathrm{~m} \\
\text { Gum) }\end{array}$ & Boian Spanțov; Gumelnița B1 & & na ("cultural level") \\
\hline Hârşova tell * & Dobrogea & Boian; Gumelnița & $150 \times 200 \mathrm{~m}$ & $10 \mathrm{~m}$ in height ( $3 \mathrm{~m}$ Boian; $7 \mathrm{~m} \mathrm{GumA})$ & Boian Spanțov; Gumelnița A2 & $\mathrm{x}$ (extensive) & Areas of household refuse, foundation trenches, dwellings \\
\hline Luncavița * & Dobrogea & Gumelnița & $75 \times 102 \mathrm{~m}$ & $3.5 \mathrm{~m}$ in height (GumA) & Gumelnița A2 & $\mathrm{x}$ (extensive) & Areas of household refuse, pits and dwellings \\
\hline Carcaliu & Dobrogea & Gumelnița & $1 \mathrm{ha}$ & $0.6 \mathrm{~m}$ in height (GumA2) & Gumelnița A2 & & Dwellings and pits \\
\hline Năvodari * & Dobrogea & Gumelnița & $120 \times 250 \mathrm{~m}$ & $1.5 \mathrm{~m}$ in height (GumA) & Gumelnița A2 & $\mathrm{x}$ (extensive) & Dwellings \\
\hline Borduşani-Popină * & Muntenia & Boian; Gumelnița & $70 \times 180 \mathrm{~m}$ & $8.7 \mathrm{~m}$ in height (Boian+GumA) & Gumelnița A2 & $\mathrm{x}$ (extensive) & Areas of household refuse, foundation trenches, dwellings \\
\hline Însurăței Popină I * & Muntenia & Gumelnița & $85 \times 275 \mathrm{~m}$ & $7 \mathrm{~m}$ in height (GumA1+A2) & Gumelnița A2 & & Areas of household refuse and dwellings \\
\hline Chitila & Muntenia & Boian; Gumelnița & 60x80 m (but partly destroyed) & na & Gumelnița A2 & & na ("cultural level") \\
\hline Şeinoiu & Muntenia & Gumelnița & $45 \times 54 \mathrm{~m}$ & 2.1-2.2 $\mathrm{m}$ in height (GumA2+B1) & Gumelnița A2 & & na \\
\hline Sultana * & Muntenia & Gumelnița & $30 \times 35 \mathrm{~m}$ (but $\sim$ half destroyed) & $2.6 \mathrm{~m}$ in height (west)- $4 \mathrm{~m}$ (east) (Gum) & Gumelnița A2 & $\mathrm{x}$ (partial) & Areas of household refuse and dwellings \\
\hline Seciu & Muntenia & Gumelnița & $60 \mathrm{~m}$ in diameter & $0.5-1.1 \mathrm{~m}$ in height (GumA) & Gumelnița A2 & & Areas of household refuse \\
\hline Vităneşti * & Muntenia & Gumelnița & $40-45 \mathrm{~m}$ in diameter & $\begin{array}{l}1 \mathrm{~m} \text { in height (GumA1); } 1.7 \mathrm{~m} \text { (natural } \\
\text { deposits); } 4 \mathrm{~m} \text { (GumA2+B1) }\end{array}$ & Gumelnița A2, B1 & & Areas of household refuse and dwellings \\
\hline Drăgănești-Olt & Muntenia & Gumelnița; Salcuța & $75 \times 123 \mathrm{~m}$ & $2-2.85 \mathrm{~m}$ in height (Gum+Salcuța) & Gumelnița A2, B1 & & na ("cultural level") \\
\hline Gumelnița & Muntenia & Boian; Gumelnița & $2 \mathrm{ha}$ & $2.3-2.4 \mathrm{~m}$ in height (Gum) & Gumelnița A2, B1 & & Dwellings \\
\hline Măriuța * & Muntenia & Gumelnița & $52 \times 85 \mathrm{~m}$ (but partly destroyed) & $1.15-1.3 \mathrm{~m}$ in height (Gum) & Gumelnița B1 & $\mathrm{x}$ (partial) & Areas of household refuse and dwellings \\
\hline Bucşani * & Muntenia & Gumelnița & $55 \times 64 \mathrm{~m}$ & $\begin{array}{l}2.86 \mathrm{~m} \text { in height (GumA+natural } \\
\text { deposits }+ \text { GumB1) }\end{array}$ & Gumelnița B1 & $\mathrm{x}$ (partial) & Areas of household refuse and dwellings \\
\hline Tangâru & Muntenia & Boian; Gumelnița & $50 \times 90 \mathrm{~m}$ & $4 \mathrm{~m}$ in height (Boian+Gum) & Gumelnița & & na ("cultural level") \\
\hline
\end{tabular}

\section{*: sites that are still excavated.}


Table 3

Taxonomic spectra for the 39 Romanian assemblages included in the study. The wild carnivores category includes Canis lupus, Vulpes vulpes, Lynx lynx, Felis silvestris, Meles meles, Martes martes, Mustela putorius, Mustela nivalis, Mustela sp., Lutra lutra, Mustelidae, Ursus arctos. Sheep/goats: Ovis aries and Capra hircus. NISP: number of identified specimens. Antler remains have been subtracted from NISP for red and roe deer, except when studies did not go into any detail on this point $(*)$. H: Hamangia; BG: Boian Giuleşti; BV: Boian Vidra; BS: Boian Spanțov; G: Gumelniţa. The names of the most reliable assemblages are in bold type (see the text, 3.1.1., for explanation). See the text (3.1.1.) for details about the Gumelnița archaeological structures that are at the bottom of the table. 


\begin{tabular}{|c|c|c|c|c|c|c|c|c|c|c|c|c|c|c|c|}
\hline \multicolumn{2}{|l|}{ Site } & \multirow{2}{*}{$\begin{array}{c}\text { Cattle } \\
\text { Bos taurus }\end{array}$} & $\begin{array}{l}\text { Sheep/ } \\
\text { goats }\end{array}$ & $\begin{array}{c}\text { Sus } \\
\text { domesticus }\end{array}$ & \multicolumn{2}{|c|}{$\begin{array}{cc}\text { Dog } & \text { Bos } \\
\text { Canis familiaris primigenius }\end{array}$} & $\begin{array}{l}\text { Cervus } \\
\text { elaphus }\end{array}$ & $\begin{array}{l}\text { Wild horse } \\
\text { Equus ferus }\end{array}$ & $\begin{array}{l}\text { Wild boar } \\
\text { Sus scrofa }\end{array}$ & $\begin{array}{l}\text { Capreolus } \\
\text { capreolus }\end{array}$ & $\begin{array}{c}\text { Wild } \\
\text { carnivores }\end{array}$ & \multirow{2}{*}{$\begin{array}{c}\text { Beaver } \\
\text { Castor fiber }\end{array}$} & \multirow{2}{*}{$\begin{array}{l}\text { Suinae } \\
\text { Sus } s p .\end{array}$} & NISP & References \\
\hline Cheia & Cheia $\mathrm{H}$ & & 1396 & 0 & 6 & 52 & 77 & & & & & & & 3370 & Bălăssescu \& Radu 2002-03; Bălășescu 2008 \\
\hline Hamangia & Ham_- $\vec{H}$ & 23 & 25 & 1 & 3 & 2 & 8 & 0 & 3 & 0 & 1 & 0 & 1 & 67 & Haimovici 1987 \\
\hline Techirghiol & Tec_H & 543 & 449 & 22 & 7 & 4 & 3 & 13 & 3 & 9 & 14 & 0 & 0 & 1067 & Haimovici \& Bălăşescu, 2006 \\
\hline Bogata & Bog_BG & 144 & 14 & 0 & 4 & 0 & 0 & 0 & 0 & 0 & 0 & 0 & 0 & 162 & Necrasov \& Haimovici 1959 \\
\hline Ciulnița & Ciu_BG & 1785 & 583 & 23 & 14 & 15 & 6 & 2 & 4 & 3 & 3 & 0 & 1 & 2439 & Bălăsescu 2003-2004 \\
\hline Isaccea & Isac_BG & 301 & 73 & 58 & 106 & 5 & 113 & 6 & 36 & 15 & 26 & 15 & 42 & 796 & Bălăsescu 2000; Bălăşescu \& Radu 2004 \\
\hline Lăceni-Măgura & Lac_BG & 66 & 83 & 15 & 9 & 1 & 6 & 1 & 3 & 3 & 9 & 1 & 13 & 210 & Bălăsescu 2002; Bălăşescu \& Radu 2004 \\
\hline Siliştea-Conac & Sil_BG & 36 & 38 & 14 & 8 & 1 & 6 & 2 & 21 & 0 & 10 & 2 & 13 & 151 & Bălăşescu \& Radu 1999 \\
\hline Vărăștiti & Var_BV & 143 & 64 & 26 & 7 & 8 & 0 & 2 & 9 & 1 & 0 & 0 & 0 & 260 & Bolomey 1966 \\
\hline Vlădiceasca & Vla_BV & 1876 & 307 & 74 & 46 & 156 & 86 & 42 & 19 & 26 & 10 & 1 & 40 & 2683 & Bălăşescu \& Udrescu 2005 \\
\hline Lăceni-Măgura & Lac_BS & 175 & 37 & 11 & 10 & 6 & 7 & 0 & 1 & 0 & 1 & 0 & 9 & 257 & Bălăsescu 2002; Bălăşescu \& Radu 2004 \\
\hline Căscioarele & Cas_BS & 223 & 31 & 0 & 7 & 0 & 10 & 0 & 0 & 1 & 0 & 0 & 65 & 337 & Bolomey 1981 \\
\hline Hârşova tell & Hva_BS & 663 & 386 & 130 & 77 & 32 & 93 & 1 & 109 & 3 & 9 & 0 & 127 & 1630 & Bălăşescu \& Radu 2004 \\
\hline Izvoarele & Izv_BS & 612 & 205 & 202 & 50 & 5 & $34 *$ & 0 & 8 & $5^{*}$ & 9 & 4 & 0 & 1134 & Necrasov \& Gheorghiu 1970 \\
\hline Radovanu & Rad BS & 224 & 67 & 85 & 12 & 0 & $22 *$ & 0 & 9 & $2^{*}$ & 5 & 0 & 0 & 426 & Necrasov 1973 \\
\hline Radovanu & Rad_BS2 & 2295 & 424 & 1012 & 130 & 1 & $154 *$ & 2 & 8 & $18^{*}$ & 59 & 7 & 0 & 4110 & Ştirbu 1980 \\
\hline Vlădiceasca & Vla GA1 & 231 & 46 & 36 & 18 & 69 & 25 & 17 & 13 & 7 & 6 & 0 & 0 & 468 & Bălăsescu et al. 2005a \\
\hline Borduşani-P. & Bord_GA2 & 1996 & 1604 & 2320 & 1343 & 75 & 509 & 35 & 757 & 154 & 323 & 97 & 722 & 9935 & Moise 1997; Bălăşescu et al. 2003b, 2005a \\
\hline Carcaliu & $\mathrm{Car}_{-} \overline{\mathrm{G}} \mathrm{A} 2$ & 118 & 14 & 61 & 13 & 17 & 166 & 2 & 72 & 4 & 0 & 4 & 0 & 471 & Haimovici 1996 \\
\hline Hârşova tell & Hva_GA2 & 618 & 1514 & 1009 & 896 & 55 & 78 & 20 & 890 & 66 & 92 & 32 & 560 & 5830 & Moise 2000; Bălăşescu et al. 2005a \\
\hline Însurăței & Ins $\overline{\mathrm{G}} \mathrm{A} 2$ & 107 & 113 & 60 & 20 & 76 & 47 & 75 & 41 & 16 & 12 & 1 & 5 & 573 & Moise 1999 \\
\hline Luncavita & Lunc_GA2 & 301 & 129 & 167 & 32 & 17 & 373 & 6 & 207 & 36 & 40 & 5 & 87 & 1400 & Bălăşescu 2003 and unpublished \\
\hline Năvodari & Nav_GA2 & 81 & 168 & 53 & 27 & 19 & 13 & 13 & 19 & 7 & 22 & 1 & 8 & 427 & $\begin{array}{l}\text { Moise 2001a } \\
\text { Mon }\end{array}$ \\
\hline Drăgăneşti-Olt & DO_GA2 & 200 & 170 & 124 & 14 & 1 & 156 & 9 & 34 & 7 & 2 & 2 & 1 & 720 & El Susi 2002 \\
\hline Gumelnița & Gum $\mathrm{GA} 2$ & 1180 & 226 & 176 & 62 & 19 & $62 *$ & 31 & 111 & $12^{*}$ & 6 & 0 & 23 & 1908 & Necrasov \& Haimovici 1966 \\
\hline Vitănești & Vit_'GA2 & 1055 & 381 & 1190 & 252 & 1368 & 1512 & 773 & 1326 & 143 & 411 & 363 & 0 & 8774 & Bălăşescu et al. 2005a \\
\hline Vlădiceasca & $\mathrm{Vla} \mathrm{GA} 2$ & 1733 & 846 & 483 & 127 & 190 & 28 & 25 & 16 & 21 & 25 & 0 & 0 & 3494 & Bălăsescu et al. 2005a \\
\hline Chitila & Chi_GA2 & 217 & 76 & 24 & 8 & 8 & 67 & 1 & 45 & 26 & 6 & 0 & 27 & 505 & Bălăşescu et al. 2003c \\
\hline Seinoiu & Sein GA2 & 59 & 10 & 8 & 1 & 6 & 0 & 9 & 3 & 1 & 0 & 0 & 0 & 97 & Bălăsescu et al. 2005a \\
\hline Sultana & Sult GA2 & 134 & 147 & 22 & 11 & 1 & 13 & 0 & 3 & 0 & 4 & 0 & 32 & 367 & Bălășescu unpublished \\
\hline Seciu & Seciu_GA2 & 55 & 48 & 55 & 4 & 1 & 38 & 0 & 47 & 7 & 1 & 2 & 51 & 309 & Popa et al. 2011 \\
\hline Bucşani & Buc_GB1 & 275 & 66 & 163 & 15 & 51 & 109 & 33 & 22 & 18 & 32 & 21 & 17 & 822 & Bălăşescu 1998 \\
\hline Căscioarele & Cas GB1 & 201 & 27 & 57 & 166 & 239 & $1193 *$ & 245 & 550 & $121 *$ & 11 & 16 & 196 & 3022 & Bolomey unp. in Bălăşescu et al. 2005a \\
\hline Măriuța & Mar GB1 & 603 & 332 & 178 & 49 & 10 & 49 & 57 & 54 & 9 & 12 & 0 & 48 & 1401 & Moise 2001b; Bălășescu unpublished \\
\hline Drăgănești-Olt & DO_GB1 & 419 & 156 & 282 & 35 & 15 & 450 & 25 & 115 & 6 & 6 & 5 & 8 & 1522 & El Susi 2002 \\
\hline Gumelnița & Gum_GB1 & 284 & 43 & 49 & 14 & 8 & $28^{*}$ & 6 & 34 & 4* & 5 & 1 & 6 & 482 & Necrasov \& Haimovici 1966 \\
\hline Vitănești & Vit GB1 & 843 & 161 & 809 & 90 & 515 & 510 & 220 & 209 & 17 & 75 & 115 & 53 & 3617 & Bălășescu \& Radu 2003 \\
\hline Vlădiceasca & Vla_GB1 & $\begin{array}{l}\begin{array}{r}43 \\
618\end{array} \\
\end{array}$ & 196 & 138 & 23 & 13 & 8 & 5 & 1 & $\begin{array}{l}11 \\
5\end{array}$ & 2 & 0 & 0 & 1009 & Bălăşsescu et al. 2005a \\
\hline Tangâru & Tan_G & 120 & 80 & 45 & 4 & 0 & 0 & 0 & 0 & 0 & 0 & 0 & 0 & 249 & Necrasov \& Haimovici 1959 \\
\hline & Structure & & & & & & & & & & & & & & \\
\hline Hârșova tell & Hva C 521 & 104 & 264 & 116 & 124 & 12 & 3 & 3 & 187 & 6 & 10 & 11 & 219 & 1059 & Moise, 2000 \\
\hline Hârşova tell & Hva C720 & 178 & 135 & 133 & 88 & 3 & 11 & 1 & 3 & 0 & 17 & 2 & 144 & 715 & Bălășescu, unpublished \\
\hline Hârşova tell & Hva_C1017 & 49 & 60 & 44 & 35 & 0 & 2 & 0 & 4 & 2 & 8 & 3 & 127 & 334 & Bălăşescu, unpublished \\
\hline Însurătei & Ins $\overline{\mathrm{L}} 4$ & 37 & 54 & 34 & 12 & 17 & 25 & 11 & 22 & 3 & 3 & 0 & 2 & 220 & Moise, 1999 \\
\hline Însurătei & $\begin{array}{l}\text { Ins L7 } \\
\text { Ins }\end{array}$ & 19 & 16 & 0 & 5 & 17 & 5 & 16 & 1 & 2 & 0 & 1 & 0 & 82 & Moise, 1999 \\
\hline Însurătạei & Ins_L8 & 33 & 28 & 12 & 2 & 29 & 16 & 35 & 5 & 4 & 4 & 0 & 1 & 169 & Moise, 1999 \\
\hline Borduşani-P. & Bord C201 & 71 & 37 & 58 & 44 & 4 & 8 & 0 & 13 & 0 & 16 & 1 & 40 & 292 & Bălăssescu et al., 2003b \\
\hline Borduşani-P. & Bord SL33 & 23 & 15 & 16 & 5 & 0 & 2 & 0 & 10 & 0 & 7 & 0 & 18 & 96 & Bălăsescu et al., 2003b \\
\hline Luncavitạ & Lunc C2 & 16 & 12 & 23 & 3 & 2 & 44 & 1 & 18 & 4 & 8 & 1 & 11 & 143 & Bălășescu, unpublished \\
\hline Luncavitata & Lunc_C4 & 26 & 11 & 24 & 0 & 2 & 18 & 0 & 22 & 2 & 4 & 1 & 4 & 114 & Bălăşescu, unpublished \\
\hline Bucşani & Buc_L2 & 58 & 13 & 29 & 1 & 12 & 14 & 6 & 5 & 8 & 9 & 5 & 4 & 164 & Bălăşescu, 1998 \\
\hline
\end{tabular}




\section{Table 4}

Species-level identification for sheep and goats remains of the five Gumelniţa tell sites selected for the establishment of kill-off patterns. See the text (3.2.1.) for explanation of the methodology. O: Ovis aries; C: Capra hircus.

\begin{tabular}{lccccc} 
Site & Cultural stage & \multicolumn{2}{c}{ Mandibles } & \multicolumn{2}{c}{ Post-cranial elements } \\
& & NISP species-level & $\%$ Ovis & NISP species-level & $\%$ Ovis \\
Hârşova tell & Gumelnița A2 & 103 & 93.2 & 332 & 76.8 \\
Borduşani-Popină & Gumelnița A2 & 58 & 82.8 & 292 & 75.0 \\
Măriuța & Gumelnița B1 & 29 & 89.7 & 82 & 76.8 \\
Vităneşti & Gumelnița A2 & 9 & 5O for 4C & 113 & 73.5 \\
Luncavița & Gumelnița A2 & 9 & 6O for 3C & 38 & 52.6
\end{tabular}

Table 5

Raw data for the sheep/goat kill-off patterns for the five Gumelniţa tell sites selected for the study (see table 2 for details). See the text (3.2.3.) for explanation of the methodology.

\begin{tabular}{|c|c|c|c|c|c|c|c|c|c|c|c|}
\hline \multicolumn{2}{|c|}{ Sheep \& goats } & \multicolumn{2}{|c|}{$\begin{array}{l}\text { Hârşova tell } \\
\text { (Gum A2) }\end{array}$} & \multicolumn{2}{|c|}{$\begin{array}{l}\text { Borduşani-Popină } \\
\text { (Gum A2) }\end{array}$} & \multicolumn{2}{|c|}{$\begin{array}{l}\text { Luncavița } \\
\text { (Gum A2) }\end{array}$} & \multicolumn{2}{|c|}{$\begin{array}{l}\text { Vităneşti } \\
\text { (Gum A2) }\end{array}$} & \multicolumn{2}{|c|}{$\begin{array}{l}\text { Măriuța } \\
\text { (Gum B1) }\end{array}$} \\
\hline Stage & Suggested age & $N$ & $\%$ & $N$ & $\%$ & $N$ & $\%$ & $N$ & $\%$ & $N$ & $\%$ \\
\hline $\mathrm{A}^{\circ}$ & $0-2$ months & 3.3 & 0.6 & 0 & & 0 & & 0 & & 0 & \\
\hline B & 2-6 months & 15.1 & 2.5 & 10 & 2.5 & 1 & 1.8 & 3 & 6.3 & 0.8 & 0.5 \\
\hline $\mathrm{C}$ & 6-12 months & 256.6 & 43.3 & 165 & 41.7 & 6.5 & 11.6 & 28 & 58.3 & 62.5 & 37.4 \\
\hline $\mathrm{D}$ & $1-2$ years & 112 & 18.9 & 96.7 & 24.4 & 15 & 26.8 & 6.3 & 13.1 & 36.4 & 21.8 \\
\hline $\mathrm{EF}$ & $2-4$ years & 69.5 & 11.7 & 38.3 & 9.7 & 10.7 & 19.1 & 8.7 & 18.1 & 41.8 & 25.0 \\
\hline G & 4-6 years & 71.8 & 12.1 & 53.3 & 13.5 & 13.2 & 23.6 & 1.3 & 2.7 & 6.5 & 3.9 \\
\hline HI & $6-10$ years & 64.7 & 10.9 & 32.7 & 8.3 & 9.6 & 17.1 & 0.7 & 1.5 & 19 & 11.4 \\
\hline & $\sum$ & 593 & & 396 & & 56 & & 48 & & 167 & \\
\hline
\end{tabular}




\section{Table 6}

Raw data for the cattle kill-off patterns for the four Gumelnița tell sites selected for the study (see table 2 for details). See the text (3.2.3.) for explanation of the methodology.

\begin{tabular}{|c|c|c|c|c|c|c|c|c|}
\hline Cattle & \multicolumn{2}{|c|}{$\begin{array}{l}\text { Hârşova tell } \\
\text { (Gum A2) }\end{array}$} & \multicolumn{2}{|c|}{$\begin{array}{l}\text { Borduşani-Popină } \\
\text { (Gum A2) }\end{array}$} & \multicolumn{2}{|c|}{$\begin{array}{l}\text { Luncavița } \\
\text { (Gum A2) }\end{array}$} & \multicolumn{2}{|c|}{$\begin{array}{l}\text { Măriuța } \\
\text { (Gum B1) }\end{array}$} \\
\hline Suggested age & $N$ & $\%$ & $N$ & $\%$ & $N$ & $\%$ & $N$ & $\%$ \\
\hline $0-6$ months & 6.6 & 6.4 & 11.9 & 7.1 & 1.3 & 2.9 & 3.3 & 4.9 \\
\hline 6-12 months & 8.6 & 8.3 & 16.3 & 9.8 & 7.1 & 15.7 & 10.1 & 15.1 \\
\hline $1-2$ years & 26.8 & 26.0 & 38.7 & 23.2 & 6.8 & 15.2 & 15.9 & 23.7 \\
\hline $2-4$ years & 15.7 & 15.2 & 45.5 & 27.2 & 14.3 & 31.8 & 13.8 & 20.6 \\
\hline 4-6.5 years & 26.3 & 25.5 & 20.5 & 12.3 & 5.2 & 11.6 & 11 & 16.4 \\
\hline $6.5-9$ years & 14.2 & 13.8 & 19.1 & 11.4 & 4.4 & 9.7 & 9.3 & 13.8 \\
\hline $9-11.5$ years & 2.8 & 2.7 & 6.1 & 3.6 & 2.8 & 6.1 & 3.3 & 4.9 \\
\hline$>11.5$ years & 2 & 1.9 & 9 & 5.4 & 3.2 & 7.1 & 0.5 & 0.7 \\
\hline$\Sigma$ & 103 & & 167 & & 45 & & 67 & \\
\hline
\end{tabular}



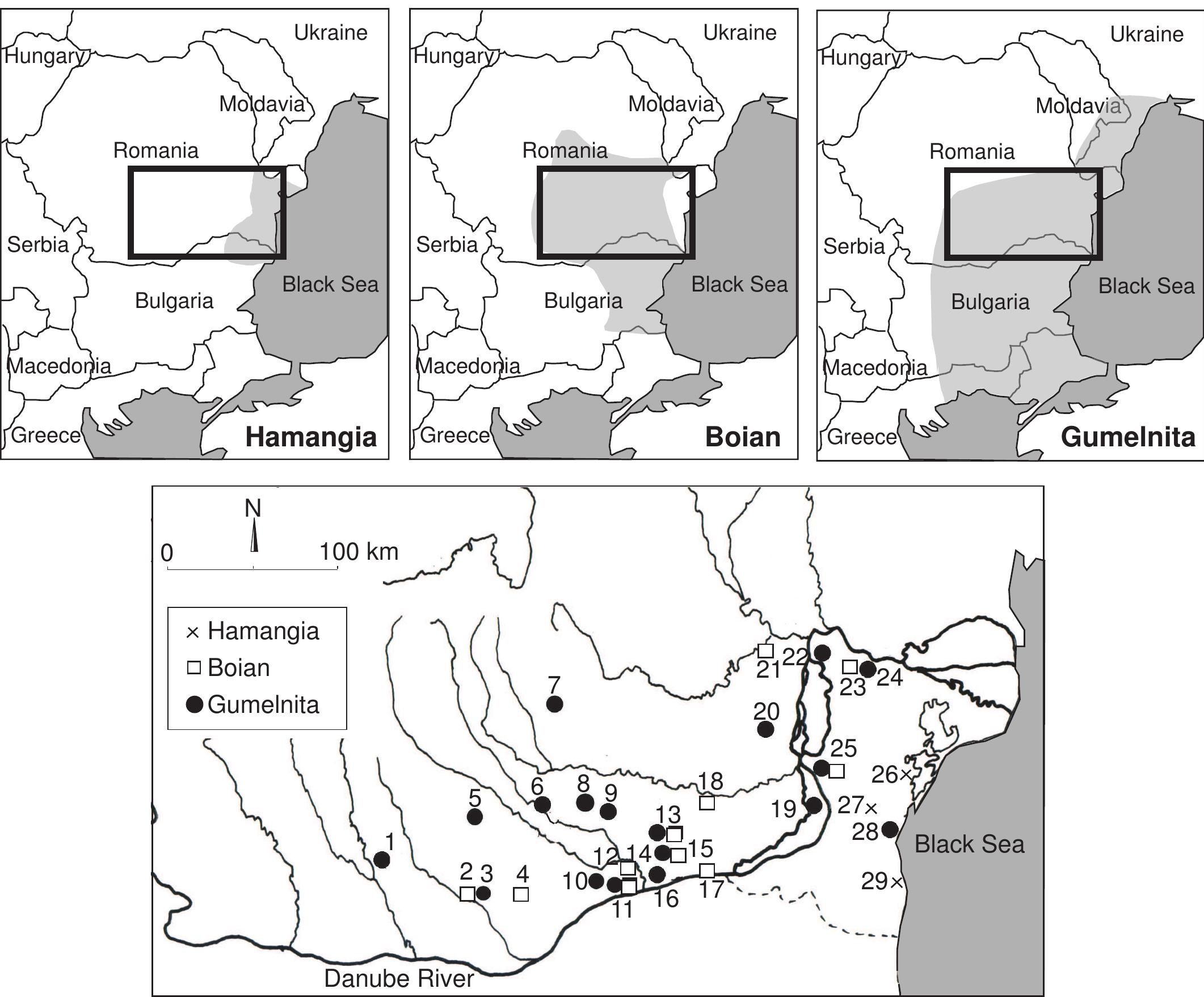


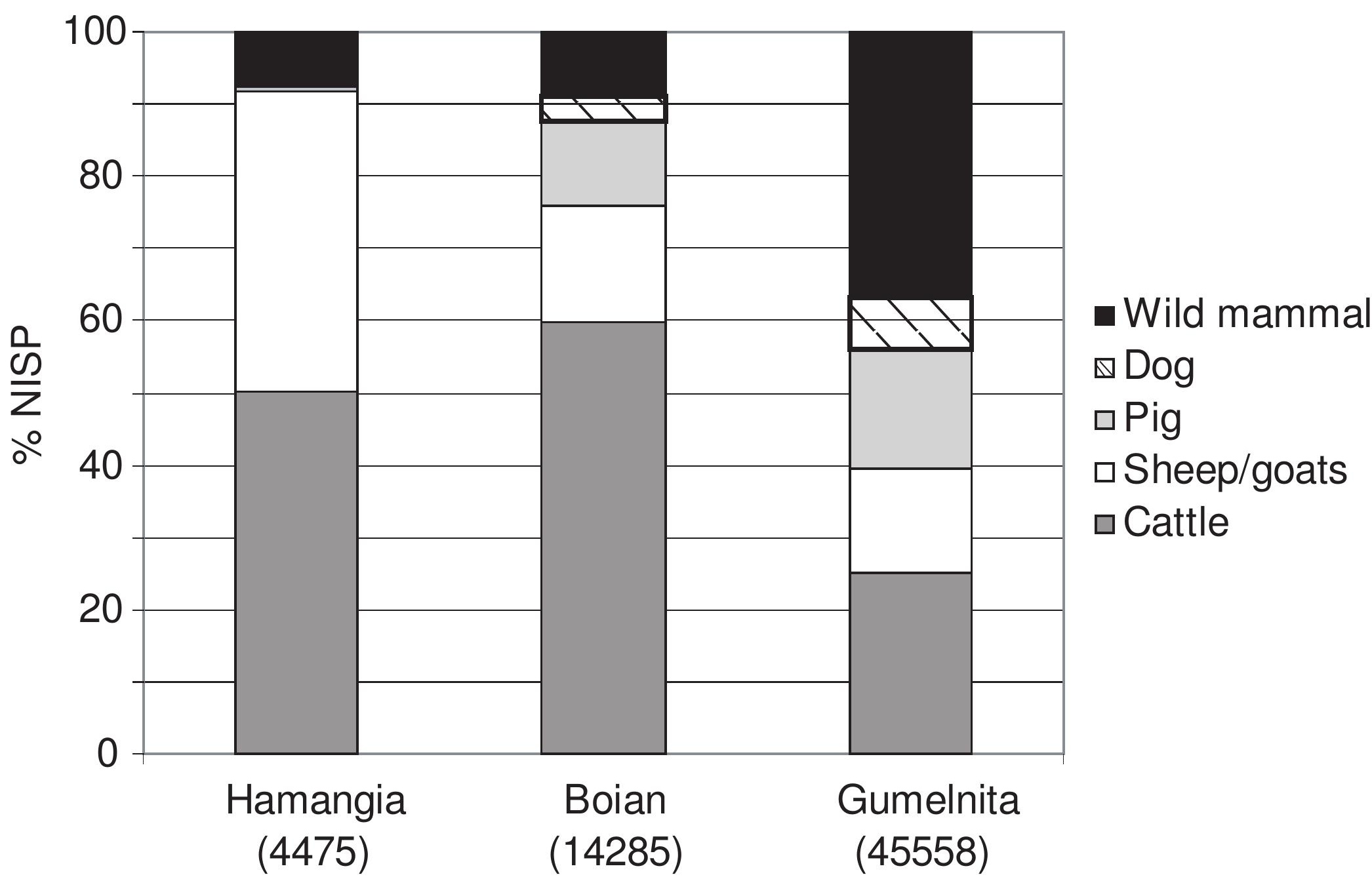




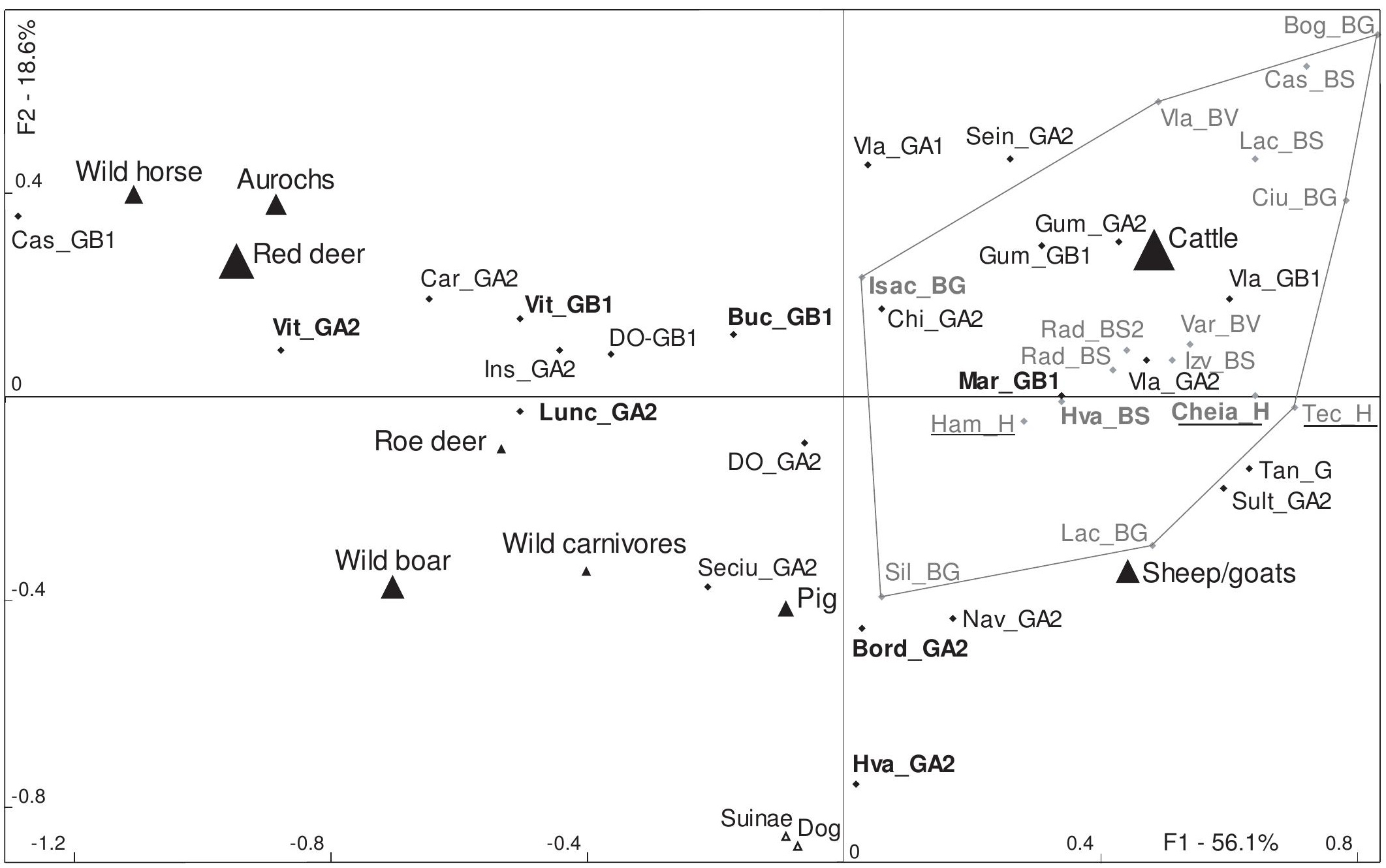




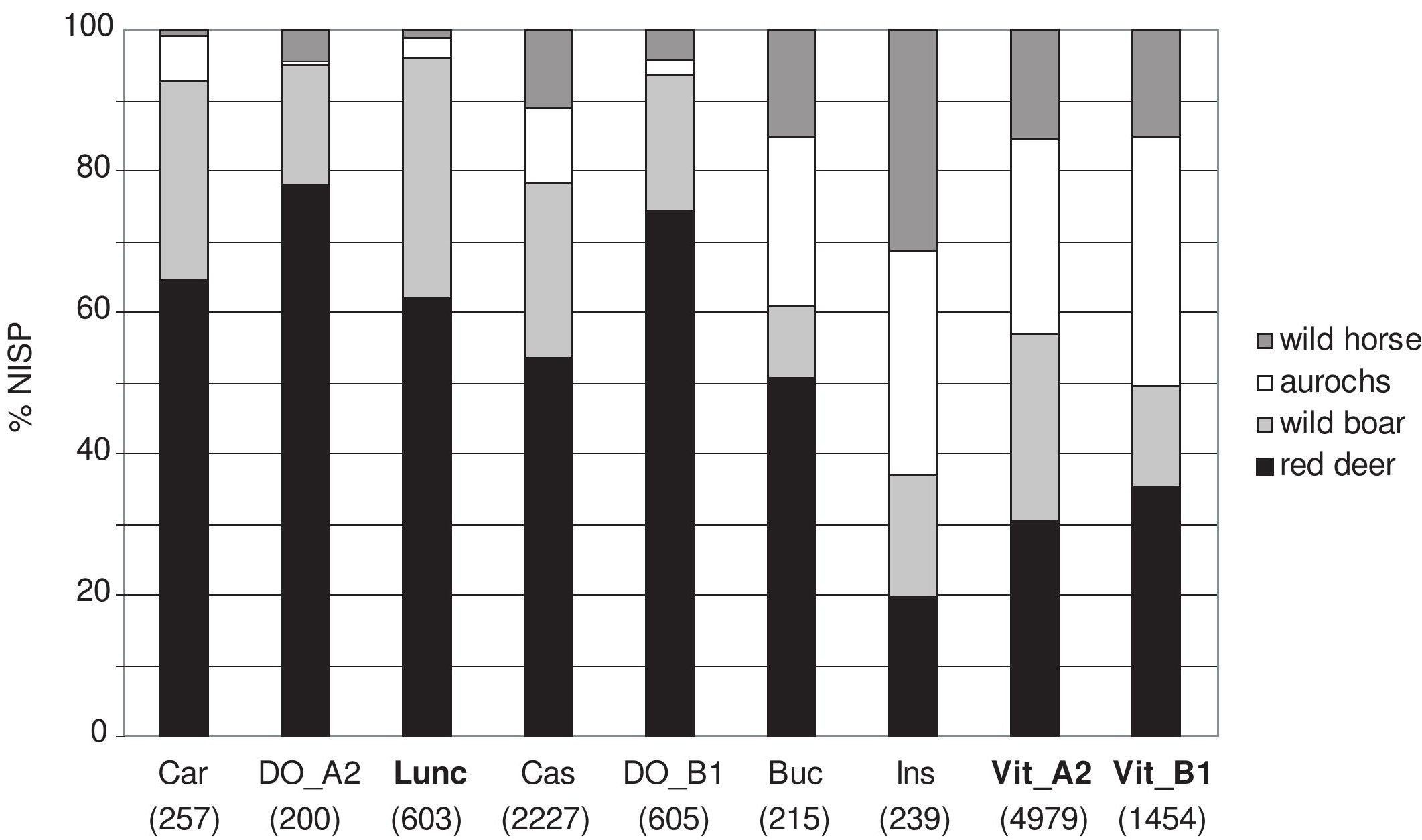




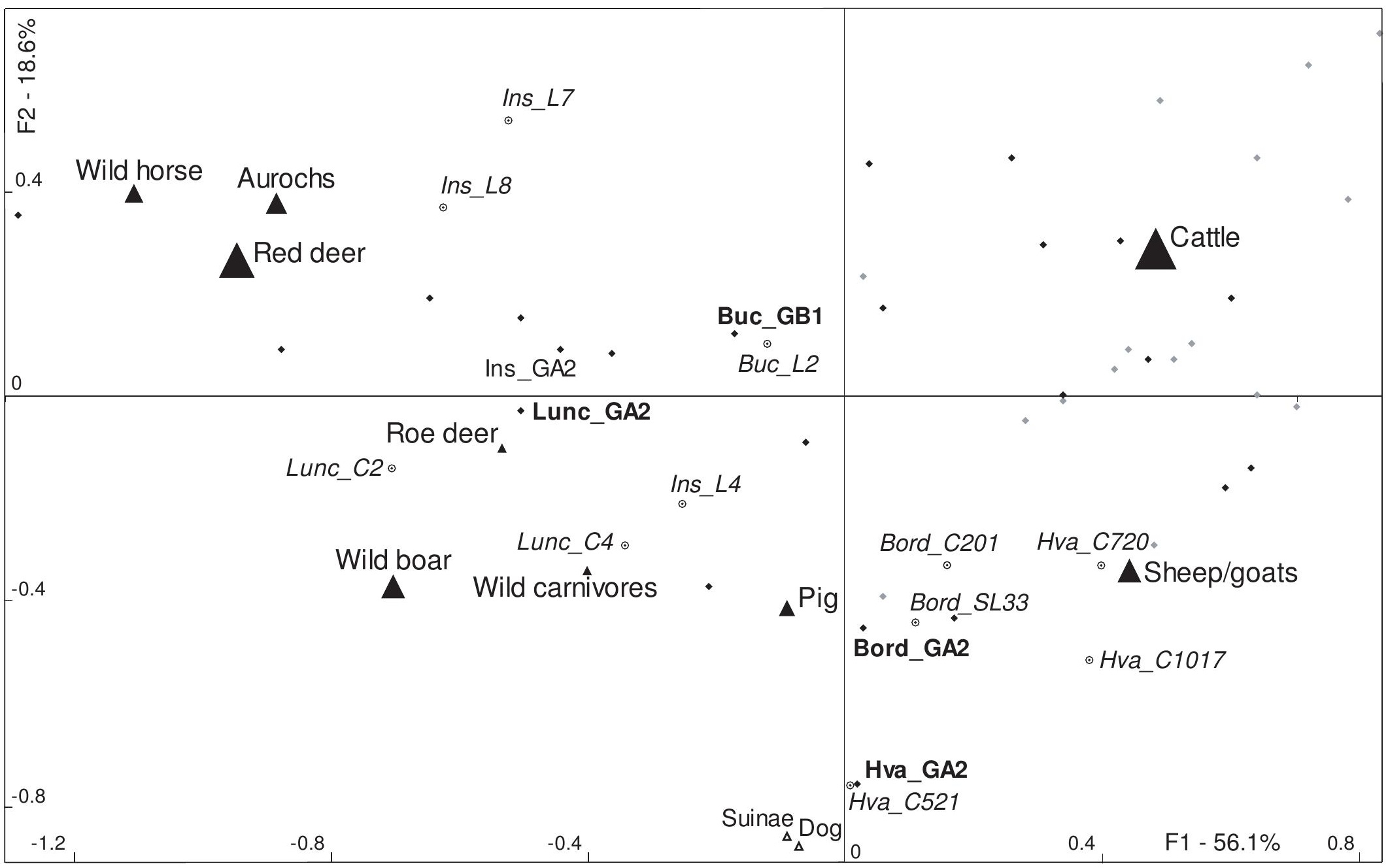


Figure7

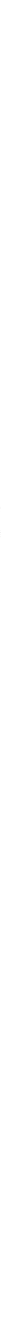



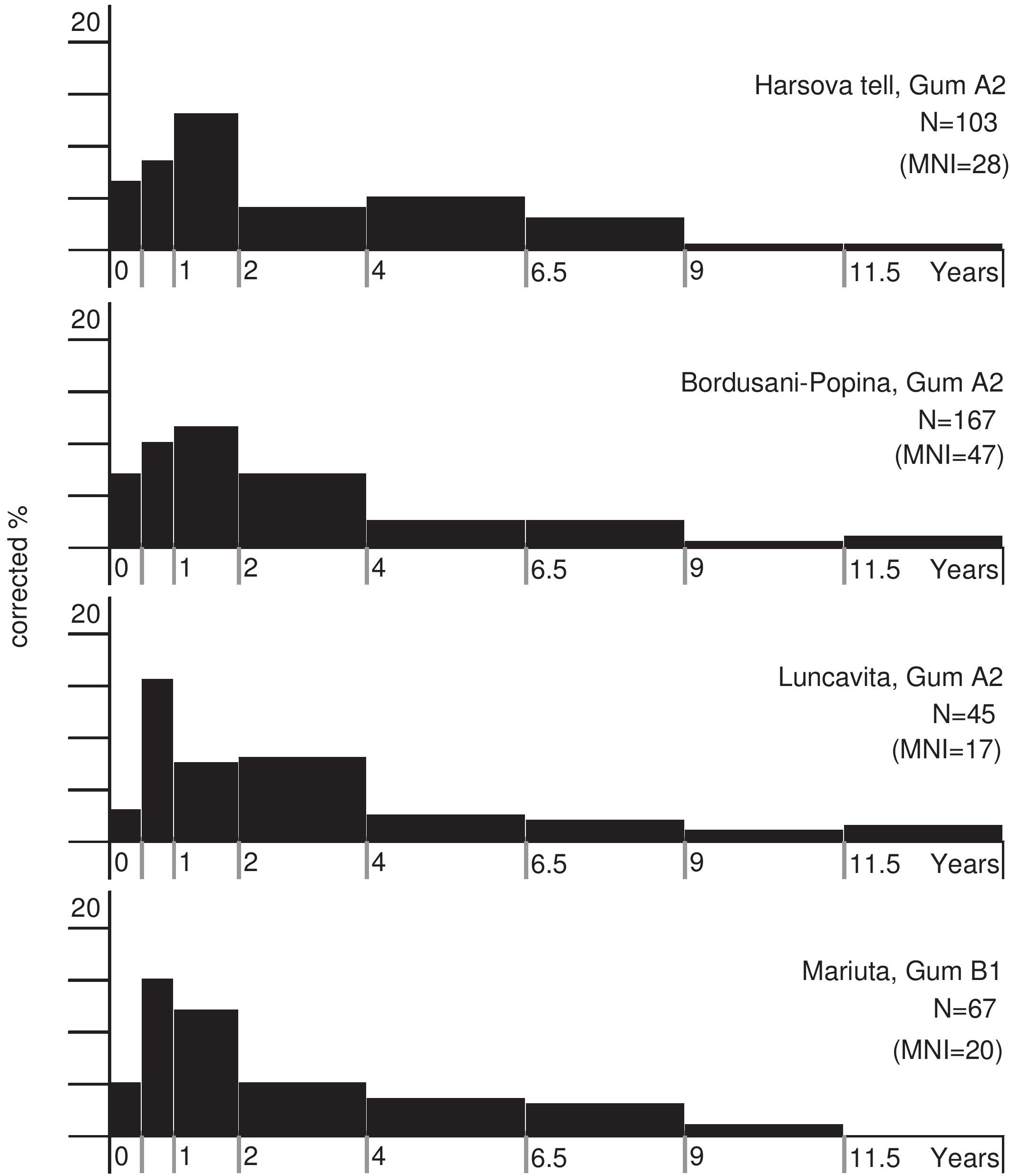